\title{
Anti-adhesion activity of phytochemicals to prevent Campylobacter jejuni biofilm formation on abiotic surfaces
}

\author{
Anja Klančnik · Katarina Šimunović • Meta Sterniša • Dina Ramić • \\ Sonja Smole Možina • Franz Bucar
}

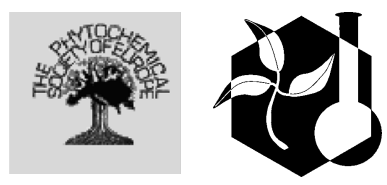

Received: 24 January 2020/Accepted: 11 March 2020/Published online: 26 March 2020

(C) The Author(s) 2020

\begin{abstract}
Biofilms provide a protective environment for pathogens such as Campylobacter jejuni, the most prevalent foodborne pathogen, and biofilm formation can enhance bacterial survival in hostile environments. Adhesion of bacteria to the different materials of industrial surfaces is the first step in biofilm formation. Modulation of bacterial adhesion and biofilm formation thus represent important targets in alternative control strategies for reduction of pathogens in food-processing environments. With the high prevalence of $C$. jejuni and the lack of effective control measures, new control strategies are needed to block adhesion and biofilm formation on food contact surfaces in the food industry, with a focus here on natural antimicrobial phytochemicals. Plants remain a poorly recognized yet vast source of such antimicrobials. Valuable phytochemicals can be obtained directly from plant materials but also from agro-food by-products and waste materials. These materials represent a source of important plant bioactive
\end{abstract}

A. Klančnik · K. Šimunović · M. Sterniša ·

D. Ramić · S. Smole Možina

Department of Food Science and Technology,

Biotechnical Faculty, University of Ljubljana,

Jamnikarjeva 101, 1000 Ljubljana, Slovenia

F. Bucar $(\bowtie)$

Institute of Pharmaceutical Sciences, Department of

Pharmacognosy, University of Graz, Universitätsplatz 4,

8010 Graz, Austria

e-mail: franz.bucar@uni-graz.at phytochemicals that are effective for prevention of bacterial adhesion. In this review, we will focus on the anti-adhesion activities of phytochemicals targeted against $C$. jejuni, on the appropriate methodologies to determine anti-adhesion effects of phytochemicals, on the mechanisms of $C$. jejuni adhesion, and thus possible targets for reduction and control of this foodborne pathogen in food processing environments.

Keywords Bioactive phytochemicals - Antiadhesion - Target mechanism - Campylobacter jejuni . Abiotic surface

\section{Introduction}

Many bacterial species have developed the unique survival strategy of biofilm formation, which provides selective advantages over their planktonic and freeexisting cells. They can attach to a surface through electrostatic and van der Waals forces, and thence start to communicate, to establish a biofilm community (Dunne 2002; Flemming et al. 2016). Further cell-cell interactions, cell signalling and bacterial replication lead to a more organised structure, with the establishment of a dense population that is encapsulated in a mainly self-produced matrix of extracellular polymeric substances (EPS). This matrix is composed of polysaccharides, proteins, nucleic acids and lipids. In biofilms, the EPS holds the cells close together, which 
results in higher concentrations of cell-produced signalling molecules, and at sufficient quantities these can promote changes in cellular behaviour and the activation of various genes. At this stage, intercellular communication leads to synergy within the community, with the diffusion of oxygen and nutrients inwards, and waste and signals outwards (Limoli et al. 2015). Further formation of the mature biofilm in its three-dimensional (3D) architecture increases the adhesion between the bacteria and with the surface, and protects the bacteria from radiation damage, dehydration, $\mathrm{pH}$ fluctuations and antimicrobial compounds (Flemming et al. 2016).

Further problems can arise from multispecies situations compared to monocultures, whereby the growth and biofilm formation of pathogenic bacteria can also be influenced by other bacterial species. For example, spoilage bacteria, such as Pseudomonas, can decompose meat through their extracellular hydrolases and penetrate deeper into food (Shirai et al. 2017). This will provide further nutrients and create potential pathways for Escherichia coli to grow and form biofilms, and consequently to penetrate and persist in the food. Thus, such mixed bacterial populations can enhance growth and biofilm formation, and consequently bacterial persistence (Sterniša et al. 2019).

Although the regulatory mechanisms of many aspects of biofilm formation still remain unclear, it is known that this involves a succession of several steps that begins with the initial and crucial step of attachment. However, the exact mechanisms of the adhesion process and the different molecules that are involved in different organisms remain to be defined. It is known that adhesion of bacteria to abiotic surfaces is mediated via non-specific (e.g., hydrophobic) interactions (Sulaeman et al. 2012), whereas their adhesion to other living cells is through specific molecular mechanisms, such as those that involve lectins, adhesin and other specific ligands (Backert and Hofreuter 2013; Svensson et al. 2014; Teh et al. 2014).

Many bacterial species have become resistant to antibiotics, such that many of the available antibiotics are no longer effective against some infections that confront patients and physicians in hospitals. Bacterial resistance mechanisms are pandemic, and they can create clinical and financial burdens on healthcare systems (O'Neill 2016). The Review on Antimicrobial Resistance (AMR) indicate that bacterial infections are the major cause of morbidity and mortality worldwide (EFSA and ECDC 2019a). As stated by the World Health Organisation (WHO), the rate of antibiotic resistance has been accelerated by over-use and misuse of antibiotics, and by poor infection prevention and control practices (World Health Organization 2015). Consequently, new effective and practical measures are needed for the control of contamination by the major foodborne pathogens in these resistant forms.

In this review, we will discuss the current understanding of these initial biofilm-forming processes that are based on the adhesion properties of bacteria to abiotic surfaces, with a focus on $C$. jejuni. We highlight that elimination of adhesion as the first important step in biofilm formation can reduce the potential for cell adaptation to the different materials of industrial surfaces, and thus prevent bacterial survival and spread through the food-production chain. Natural extracts and isolated pure phytochemicals will be the focus as anti-adhesion antimicrobials. Furthermore, we will provide a literature overview of methods used to determine anti-adhesion effects of phytochemicals on Campylobacter spp. adhering to abiotic surfaces. Additionally, we will evaluate and compare the efficacy of some of these methods to detect the anti-adhesion effect of thymol and carvacrol in vitro. Finally, we will provide an overview of important targets for anti-adhesion activity of phytochemicals against $C$. jejuni and thus expose the importance of the study of mechanisms of antimicrobial action of phytochemicals.

\section{Campylobacter as a food safety problem and a model to study anti-adhesion strategies}

According to the regulatory agencies, including the US Food and Drug Administration and the ECDC, alternative strategies are urgently needed for the control of Campylobacter spp. (Kaakoush et al. 2015). Thermophilic Campylobacter spp., mainly $C$. jejuni, are Gram-negative spiral, rod-shaped or curved, and bipolar flagellated motile bacteria which grow under microaerobic conditions $\left(85 \% \mathrm{~N}_{2}, 3-5 \%\right.$ $\mathrm{CO}_{2}$, and $5-10 \% \mathrm{O}_{2}$ ) optimally at $42{ }^{\circ} \mathrm{C}$, but always above $30{ }^{\circ} \mathrm{C}$ (Rovira et al. 2006). As human pathogenic intestinal bacteria they can be transmitted into the human food chain from the environment, through infected animals or contaminated food. $C$. 
jejuni is a common gut commensal of several animal species, especially birds. The route from environmental contaminant to chicken caeca, to poultry carcass contaminant, and finally, to human disease agent contains many hurdles. However, C. jejuni can surmount these hurdles, to represent a major public health problem in the food industry, as the cause of campylobacteriosis, the most common bacterial gastrointestinal infection throughout the world (EFSA and ECDC 2018; Kaakoush et al. 2015). In the latest EFSA report for 2018, beside Salmonella species, Campylobacter is the second most frequently reported pathogenic agent which accounted for 524 outbreaks or $10.2 \%$ of total (5146) food-borne and waterborne outbreaks reported in the EU in 2018. Large Campylobacter outbreaks ( $>100$ cases of illness) were reported in Hungary, France and Sweden (EFSA and ECDC 2019b).

Campylobacter spp. persist and survive outside of the host in environments that are detrimental to them, which represents an enormous problem in the food industry. The main contributions are due to the spread of Campylobacter resistance through intensive use of antimicrobial agents, combined with the international trade in raw materials and food products. The European Food Safety Authority and the European Centre for Disease Control have reported increased frequencies of these antibiotic-resistant pathogenic bacteria, which show high resistance to the more widely used antibiotics. For example, the recently reported prevalence of ciprofloxacin resistant $C$. jejuni isolates from humans was $57.7 \%$, and for Campylobacter coli, $63.5 \%$, as also for tetracycline resistant $C$. jejuni of $45.4 \%$ and $C$. coli of $68.3 \%$. The prevalence of resistant strains is even higher in broiler chickens, with C. jejuni strains showing $66.9 \%$ ciprofloxacin resistance and $50.7 \%$ tetracycline resistance, with still increasing rates and worse situations in southern European countries (EFSA and ECDC 2019a, b).

This growing resistance to antimicrobials has been mainly attributed to mutations in specific genes, or to be conferred by efflux pumps. These efflux pumps can limit the access of antibiotics to their targets by actively pumping them out of the cell, and thereby preventing the intracellular concentrations that are needed for their lethality (Smole Možina et al. 2011). In biofilms, Campylobacter spp. are also protected against antimicrobial substances, as these can only penetrate slowly through the biofilm layers.
Furthermore, while the sublethal antibiotic concentrations that such biofilm bacteria are exposed to can result in slower growth, this can also promote the expression of resistance genes.

Campylobacter appear to be unusual food-borne pathogens, as they lack many of the adaptive responses to environmental stresses, although they can still survive under the conditions used during food processing and preservation. Several mechanisms appear to be involved in the Campylobacter survival strategy, including dynamic adaptation (McDougald et al. 1998) and transformation into a viable-but-not-culturable (VBNC) state (Rollins and Colwell 1986), both of which are promoted by high genetic heterogeneity. Campylobacter spp. can also form monospecies biofilms (Joshua et al. 2006) and colonise pre-existing biofilms. They can form different biofilm structures attached to a surface, as a pellicle formed at the surface of a liquid, and as aggregates that float in liquid cultures (Joshua et al. 2006). Attachment of Campylobacter spp. and formation of biofilms on foodcontact surfaces has been shown, particularly for food processing environments, such as stainless steel, glass and plastic (Joshua et al. 2006; Teh et al. 2014). Also, adhesion of Campylobacter spp. to the surface of protozoa can increase the transmission of infections, while their adhesion to the surfaces of human and animal intestinal cells promotes their pathogenicity, with the consequent effects on human and animal health (Indikova et al. 2015; Bolton 2015).

Prevention of Campylobacter spp. adhesion in the first place will thus reduce these sources of further contamination that biofilms represent (Indikova et al. 2015). Furthermore, this will limit Campylobacter spp. infections in the early stages of their development, and hence avoid or reduce the exposure of their biofilms to antibiotics, as this represents a further risk for the development of bacterial resistance. This will also serve to avoid potential adverse effects of antimicrobials on the host microbiome (Yin et al. 2019).

Thus, it is important to discuss the use of antimicrobial agents through alternative approaches to limit the increasing Campylobacter spp. resistance to antibiotics. This might be achieved by using phytochemicals as antimicrobial agents that can prevent Campylobacter spp. adhesion, and thus combat bacterial infections without providing selection pressure for the emergence of further antibiotic-resistant 
bacteria. Additionally, there is the need to sufficiently investigate the mechanisms of adhesion of Campylobacter to abiotic surfaces, to provide insight into different targets in this novel anti-Campylobacter antiadhesion strategy (Fig. 1).

\section{Phytochemicals for the prevention of biofilm formation}

The use of phytochemicals in infection medicine gradually diminished as they were replaced by antibiotics. This situation has, however, become reversed more recently as a result of increased antibiotic resistance, and as phytochemicals often show fewer side effects compared to synthetic drugs (Petrovska 2012). Indeed, plant extracts with anti-adhesive activities offer advantages over other antimicrobials as they show no deleterious effects on the host microbiota (Klemm et al. 2010).

Plants produce numerous highly diverse secondary metabolites, many of which have been optimised through evolution for specific biological functions, and which are still far from being exhaustively investigated (Atanasov et al. 2016). These phytochemicals are often referred to as phytonutrients, and they are natural bioactive compounds that can be found in foods like vegetables, fruit, whole grain products, nuts and seeds, legumes, tea and dark chocolate. Although there are tens of thousands of phytochemicals in plants, only a small number have been purified and studied (Cao et al. 2017; Singh and Chaudhuri 2018). Due to their potential benefits, scientific evaluation of various pharmacological effects of phytochemicals has increased throughout the world more recently. Indeed, as reported by the

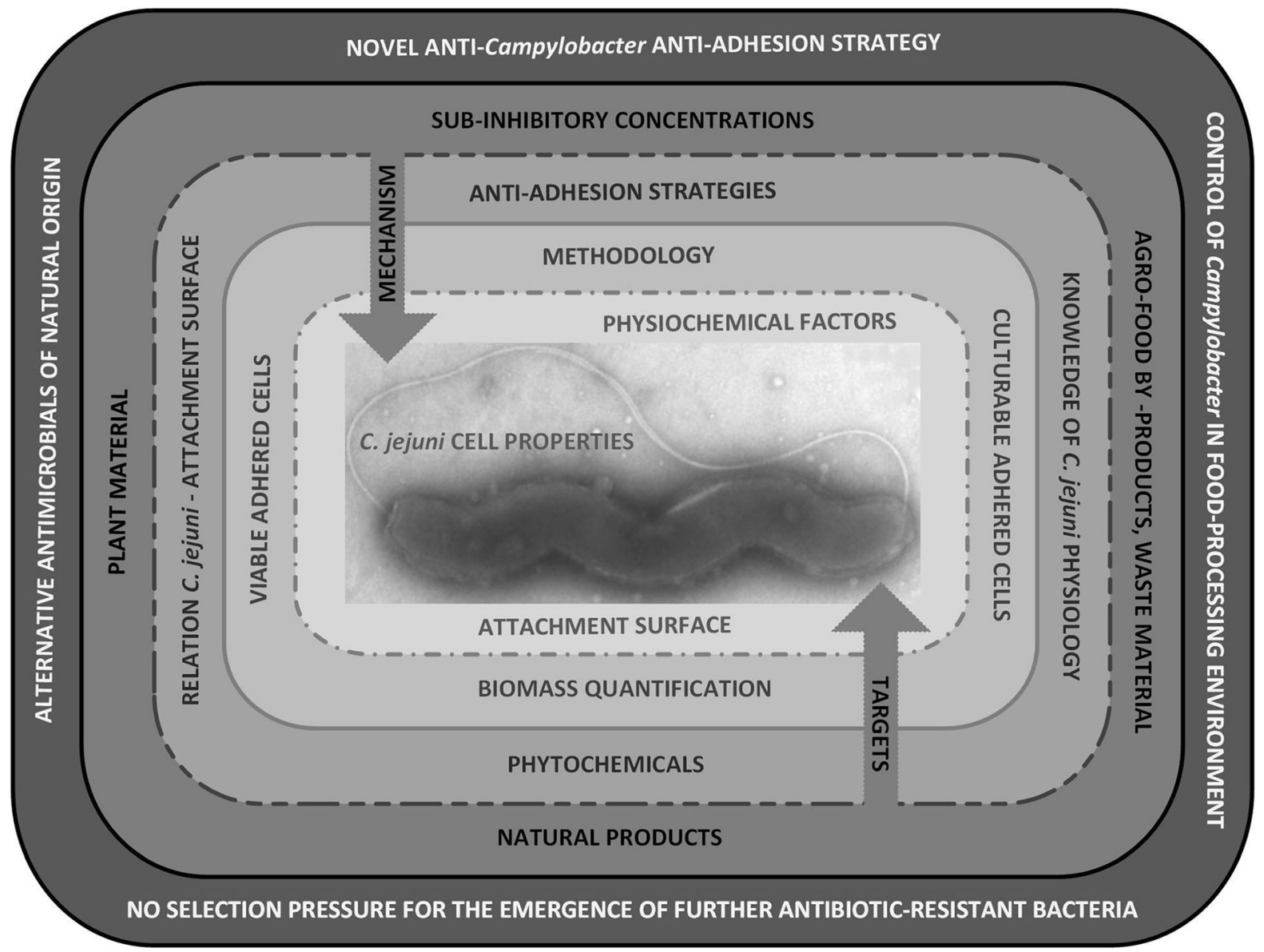

Fig. 1 The scheme of factors involved in adhesion of Campylobacter to abiotic surface, to provide insight into different targets and to present novel anti-Campylobacter anti-adhesion strategies by phytochemicals 
World Health Organisation, more than $80 \%$ of populations from developing countries still depend on traditional medicines for their primary health care, and these are mainly plant based (World Health Organisation 2019). Among small molecule anti-infectives, natural products still play a major role. In a report of Newman and Cragg only $33 \%$ of small molecule infectives approved between 1981 and 2014 are of pure synthetic origin (Newman and Cragg 2016).

Plants synthesise phytochemicals as part of their defence against pathogens, and many of these have effective antimicrobial activities. The biodiversity of the sources of phytochemicals provides unique and renewable resources for the discovery of novel biological activities (Bacanl1 et al. 2017; Chen et al. 2018; Curti et al. 2017; Vinayagam et al. 2017; Zhao et al. 2017). In this review we will focus on the antiadhesion and anti-biofilm activities of some of the known bioactive phytochemicals.

Plants can produce a large number of diverse bioactive compounds, with $>8000$ different phenolic compounds characterised to date. Fruit and vegetables have been the primary sources of these natural antioxidants and antimicrobials (Altemimi et al. 2017). Even less investigated in terms of bioactive chemicals are edible mushrooms (Kalač 2009; Wang et al. 2014) which have also been covered by this review.

Here, we present the first report on the methodologies used for evaluation of Campylobacter spp. adhesion to abiotic surfaces, and of the anti-adhesion activities of phytochemicals (Fig. 1). Recent progress in alternative antimicrobials has focused on the identification and evaluation of the properties of bioactive phytochemicals as agriculture by-products, or as by-products of other raw materials that are rich in these bioactive compounds. Alternative approaches are needed to control Campylobacter spp. using phytochemicals, probiotic bacteria, or bacteriophages, with investigations of their potential mechanism(s) of actions (Upadhyay et al. 2019).

Collectively, C. jejuni, the most prevalent cause of campylobacteriosis, is used as the model system to define novel strategies to combat contamination and infection. Currently, there is no effective control strategy, as the Campylobacter spp. 'lifestyle' enables them to withstand stress in the environment, both outside and within their hosts. We will review the possibility to target the adhesion of Campylobacter spp. to different materials of industrial surfaces, and their formation of biofilms. Here, $C$. jejuni can be used as a model to study the mechanisms that these bacteria use to adhere to surfaces, which is crucial for the application of novel control strategies. These antiadhesion strategies will thus allow modulation of Campylobacter spp. virulence and elimination of infections at the early stages of bacterial adhesion. Only a few studies have presented such alternative strategies using low doses of bioactive phytochemicals, pure compounds or phytochemicals obtained as agro-food by-products. Additionally, we investigate the adhesion mechanism involved, an understanding of which is crucial for the application of such novel antimicrobial strategies. Finally, we will provide an overview of modern methods to determine the adhesion properties of Campylobacter to abiotic surfaces.

\section{Determination of Campylobacter adhesion and biofilm formation on abiotic surfaces}

Biofilm formation is a multifactorial process that comprises different stages that are governed by different physical and chemical processes, and these all begin with the initial attachment. Adhesion of $C$. jejuni to abiotic surfaces is mediated by the following (Sulaeman et al. 2012; Indikova et al. 2015; Bohinc et al. 2014; Šikić Pogačar et al. 2016; Trošt et al. 2016; Klančnik et al. 2017a, b, 2018a, b):

1. The properties of the microbial cells, which include: their cell surface hydrophobicity and charge; their cell morphology, membranes, membrane proteins, aggregation, flagellation and motility; the host cell proteins, fatty-acid metabolism, intracellular transport and chaperones; their quorum-sensing (QS) and signalling molecules; their chemotaxis, stress responses and extracellular polymeric matrix formation.

2. The surface properties, such as hydrophobicity, electric charge and surface roughness.

3. The physicochemical factors, fluid properties and environmental conditions, including polarity, flow velocity, $\mathrm{pH}$, ionic strength, temperature, atmosphere, presence of salts, antimicrobials, nutrient availability and different media.

Collectively, the internal microbial properties provide possible detection targets in the methods used 
to evaluate anti-adhesion and anti-biofilm activities of phytochemicals. However, Campylobacter spp. can adhere to inert surfaces of different materials used in different industries, such as stainless steel, glass fibre, glass beads and coverslips, nitrocellulose membranes, and various plastics (Sulaeman et al. 2012; Teh et al. 2014; Šikić Pogačar et al. 2015; Klančnik et al. 2017b). Indeed, the most commonly used model for determination of anti-adhesion activities of phytochemicals is polystyrene microtiter plates, followed by stainless steel coupons of diverse surface roughness, and glass surfaces (Bezek et al. 2016; Klančnik et al. 2017b, 2018b; Wagle et al. 2019). It is important to include abiotic surfaces with different degrees of roughness, to thus present different in vivo conditions of surface irregularities, which have been shown to provide the cell shelter that is relevant for biofilm formation in food processing facilities (Bohinc et al. 2014).

The anti-adhesion and anti-biofilm activities of plant-based compounds also depend on the origin of the Campylobacter strain, its growth phase, the addition of glucose to the growth medium, and the incubation time (Reeser et al. 2007). The only strains used so far to determine such anti-adhesion activities of plant compounds have been the reference strains of C. jejuni NCTC 11168 (Parkhill et al. 2000) and $C$. jejuni ATCC33560 (Hyytiäinen and Hänninen 2012), and the food isolates C. jejuni K49/4, C. jejuni 225421 , and two mutants of $c m e B$ and luxS of $C$. jejuni NCTC 11168.

Furthermore, bacterial cell concentrations need to be taken into account, as these affect bacterial growth and the rate of cell adherence, and can influence the anti-adhesion or anti-biofilm activities of phytochemicals. For research purposes, standardised concentrations of $C$. jejuni of $10^{5}$ to $10^{6} \mathrm{CFU} / \mathrm{mL}$ have been most commonly used (Bezek et al. 2016; Castillo et al. 2014; Klančnik et al. 2017b, 2018b), and the followed parameters have been used: (1) media: Mueller-Hinton broth, Campylobacter enrichment (Bolton) broth or Brucella broth; (2) incubation conditions: microaerophilic $\left(5 \% \mathrm{O}_{2}, 10 \%\right.$ $\mathrm{CO}_{2}, 85 \% \mathrm{~N}_{2}$ ) or aerobic atmospheres, and temperatures of 20,37 and $42{ }^{\circ} \mathrm{C}$ (Bezek et al. 2016; Castillo et al. 2014; Klančnik et al. 2017b, 2018b; Wagle et al. 2019).

It is very important to select concentrations of phytochemicals that do not influence the bacterial growth (sub-inhibitory), to limit the potential Campylobacter resistance. Thus, minimal inhibitory concentrations (MICs) according to the European Committee on Antimicrobial Susceptibility Testing (EUCAST) or Clinical Laboratory Standards Institute (CLSI) guidelines have to be determined for each phytochemical tested, and for each $C$. jejuni strain tested. Additionally, the influence on bacterial growth kinetics must be determined for the MICs, and also for selected subinhibitory concentrations. According to the literature, sub-inhibitory concentrations for growth effects have been used, mostly as $0.1 \times$ MIC to $0.5 \times$ MIC. Furthermore, whatever methods are used for evaluation of the anti-adhesion and anti-biofilm activities of phytochemicals, care is needed in terms of the concentration of solvent used in the preparation of the phytochemicals, and the relevant controls need to be included. We have found that solutions with $1 \%$ ethanol or DMSO do not influence $C$. jejuni adhesion to abiotic surfaces (results not shown, Šimunović et al. 2020), although higher concentrations have not been tested.

Collectively, bacteria inoculated in broth are incubated with the investigational phytochemicals. After the addition of the phytochemicals at sublethal concentrations, short incubation times of up to $24 \mathrm{~h}$ are used to study anti-adhesion processes, and with over $24 \mathrm{~h}$ used to study anti-biofilm activities. After the incubation and the interactions of the bacteria in terms of their contact with the investigational surface, there is the need to first remove the unattached bacteria, with a wash with phosphate-buffered saline (PBS). Further different direct and indirect methods can be used to provide insights into the various parameters investigated, and the further specific detection steps will depend on the methodology selected. The most critical point for the anti-adhesion or anti-biofilm determination of these phytochemicals is to adopt a relevant method that is reliable and robust enough to be carried out under various environmental conditions (Šikić Pogačar et al. 2016; Trošt et al. 2016; Klančnik et al. 2017b, 2018a).

The quantification of Campylobacter adhesion is based on various indirect approaches, such as biomass determination, cultivability, viability, metabolic activity, or other cell properties, with most of these determined in microtiter plates. According to the target parameters, the different methods will provide different data. To evaluate and quantify the anti- 
adhesion and anti-biofilm activities of the phytochemicals, it is advisable to use different methods to measure several relevant parameters. At the same time, not all methods are always feasible, as unexpected reactions of phytochemicals can occur with the reagents used. Once the data have been obtained, they need to be taken through different data processing formats. The methods generally used to evaluate adhesion and biofilm formation of $C$. jejuni, and the inhibitory effects of phytochemicals, are collected in Table 1.

One of the most commonly used methods to determine anti-adhesion and anti-biofilm activities is based on biomass reduction. These studies used different dyes, such as crystal violet (Klančnik et al. 2017b) and safranin (Castillo et al. 2014), which bind non-specifically to negatively charged surface molecules, and thus bind to both the bacteria and the extracellular biofilm components. In this indirect method, the absorbance of the dye used is then determined, to evaluate the adherence of the bacteria.

At the same time, these dyes can also bind to the phytochemicals themselves. For this reason, when using such non-specific dyes, there is also the need to determine whether the phytochemicals can form a conditioning layer, and the phytochemical interaction with the dye must be included. When the read-out data of absorbance are obtained, the negative control absorbance must also be determined. The mean absorbance as a measure of bacterial adhesion is thus calculated according to Eq. (1) (Harvey et al. 2007):

$\Delta \overline{\mathrm{A}}=\sum_{i=1}^{n}\left(\frac{A-\overline{\mathrm{A}}_{\mathrm{o}}}{n}\right)$

where $\Delta \overline{\mathrm{A}}$ is the mean bacterial absorbance, $\overline{\mathrm{A}}_{\mathrm{o}}$ is the arithmetic mean of the absorbance of the wells with the negative control, and $\mathrm{n}$ is the number of wells with the inoculated bacterial strain. Thus, the reduction of bacterial adhesion in the presence of the natural compounds can be calculated as the inhibition of each parameter (expressed as a percentage) using Eq. (2) (Jadhav et al. 2013):

$\operatorname{Inhibition}(\%)=\left(1-\left[\frac{T}{C}\right]\right) \times 100$ where $C$ is the mean for the control samples that contain bacteria in medium without the plant phytochemical, and $T$ is the mean for the treated samples that contained the bacteria in medium with the phytochemicals.

Recently, Wagle et al. (2019) used 2,3,5-triphenyltetrazolium chloride (generally known as TTC) for adhesion and biofilm assays, with staining of live adhered or biofilm cells. These were then air-dried, dissolved in $20 \%$ acetone in ethanol, and measured for absorbence at $500 \mathrm{~nm}\left(\mathrm{~A}_{500}\right)$.

The number of adhered or biofilm cells can be evaluated indirectly by the viability of the cells, in terms of the cell cultivability. Cell cultivability is determined on agar plates using the colony counting plate technique, and is expressed as colony forming units (CFU) (Vesterlund et al. 2005; Gamble and Muriana 2007; Klančnik et al. 2017b). The bacterial cell growth in broth to a certain turbidity can also be measured (i.e., optical density [OD]) (Bezek et al. 2016; Klančnik et al. 2017b, 2018a; Šikić Pogačar et al. 2016). To determine the cultivability of adhered or biofilm cells, after rinsing off the unattached cells with PBS, the adhered or biofilm cells need to be detached using sonication, glass beads or scraping (Bezek et al. 2016; Šikić Pogačar et al. 2016; Klančnik et al. 2017b, 2018a; Wagle et al. 2019), and then diluted in PBS. Again, the bacterial cells are then calculated using the colony counting plate technique, and expressed as CFU/mL (ISO 4833). These data expressed as $\mathrm{CFU} / \mathrm{mL}$, or as CFU/surface, are compared to the control. When turbidity is measured, the surface is washed/rinsed with PBS, fresh medium is added, and the cells are detached and allowed to grow, followed by optical density measurements compared to the control.

The number of adhered or biofilm cells can be evaluated indirectly by the viability of the cells according to the cell metabolism. However, this approach also detects cells that are in a state of very low metabolic activity. These cells cannot therefore divide, although they are alive and might not be considered by plate counting methods (and hence are VBNC). Campylobacter enter the VBNC state as a response to stress, due to adverse nutrient, temperature, osmotic and oxygen conditions, and also due to addition of antimicrobial compounds. Interestingly, there have only been two methods used in the literature 
Table 1 Methods generally used to evaluate the adhesion and biofilm formation of Campylobacter jejuni, and the inhibitory effects of phytochemicals

\begin{tabular}{|c|c|c|c|c|c|c|}
\hline $\begin{array}{l}\text { Parameter } \\
\text { evaluated }\end{array}$ & Method & Conditions/work & Processing & Surface & Assay & References \\
\hline \multirow[t]{3}{*}{$\begin{array}{l}\text { Biomass } \\
\text { determination }\end{array}$} & Crystal violet assay & $\begin{array}{l}\text { Microaerobic } \\
\text { atmosphere, } \\
42{ }^{\circ} \mathrm{C} \text { for } 24 \mathrm{~h}\end{array}$ & $\begin{array}{c}\text { Wash, dry, } 1 \% \text { Crystal } \\
\text { violet (wt/vol), } \mathrm{A}_{584}\end{array}$ & $\begin{array}{l}\text { Polystyrene } \\
\text { microtiter } \\
\text { plates }\end{array}$ & Adhesion & $\begin{array}{l}\text { Trošt et al. } \\
\text { (2016), } \\
\text { Klančnik } \\
\text { et al. } \\
\text { (2017b) }\end{array}$ \\
\hline & Crystal violet assay & $\begin{array}{l}\text { Microaerobic } \\
\text { atmosphere, } \\
37^{\circ} \mathrm{C} \text { for } 48 \mathrm{~h}\end{array}$ & $\begin{array}{c}\text { Wash, dry, } 1 \% \text { Crystal } \\
\text { violet (wt/vol), } \mathrm{A}_{570}\end{array}$ & $\begin{array}{l}\text { Polystyrene } \\
\text { microtiter } \\
\text { plates }\end{array}$ & $\begin{array}{l}\text { Biofilm } \\
\text { formation }\end{array}$ & $\begin{array}{l}\text { Duarte et al. } \\
(2015,2016)\end{array}$ \\
\hline & Safranin assay & $\begin{array}{l}\text { Microaerobic } \\
\text { atmosphere, } \\
42{ }^{\circ} \mathrm{C} \text { for } 72 \mathrm{~h}\end{array}$ & $\begin{array}{l}\text { Wash, dry, 1\% Safranin } \\
\text { (wt/vol), } \mathrm{A}_{492}\end{array}$ & $\begin{array}{l}\text { Polystyrene } \\
\text { microtiter } \\
\text { plates }\end{array}$ & $\begin{array}{l}\text { Biofilm } \\
\text { formation }\end{array}$ & $\begin{array}{l}\text { Castillo et al. } \\
(2014,2015)\end{array}$ \\
\hline $\begin{array}{l}\text { Attached, } \\
\text { biofilm cells }\end{array}$ & $\begin{array}{l}\text { 2,3,5- } \\
\text { Triphenyltetrazolium } \\
\text { chloride }\end{array}$ & $\begin{array}{l}\text { Aerobic } \\
\text { atmosphere, } \\
20 / 37^{\circ} \mathrm{C} \text { for } \\
24 / 48 \mathrm{~h} \text {; medium/ } \\
\text { chicken meat } \\
\text { juice }\end{array}$ & $\begin{array}{l}\text { Wash, dry, } 0.05 \% \\
\text { Triphenyltetrazolium } \\
\text { chloride (wt/vol), } \\
\text { A }_{500}\end{array}$ & $\begin{array}{l}\text { Polystyrene } \\
\text { microtiter } \\
\text { plates, } \\
\text { stainless steel } \\
\text { coupons }\end{array}$ & $\begin{array}{l}\text { Adhesion, } \\
\text { biofilm } \\
\text { formation }\end{array}$ & $\begin{array}{l}\text { Wagle et al. } \\
\text { (2019) }\end{array}$ \\
\hline \multirow[t]{3}{*}{$\begin{array}{l}\text { Cultivability of } \\
\text { adhered cells }\end{array}$} & Plating $(\mathrm{CFU} / \mathrm{mL})$ & $\begin{array}{l}\text { Microaerobic } \\
\text { atmosphere, } \\
42{ }^{\circ} \mathrm{C} \text { for } 1 / 24 / \\
48 / 72 \mathrm{~h}\end{array}$ & $\begin{array}{l}\text { Wash, detach cells } \\
\text { (vortex, glass beads), } \\
\text { plate }\end{array}$ & $\begin{array}{l}\text { Stainless steel } \\
\text { coupons }\end{array}$ & Adhesion & $\begin{array}{l}\text { Bezek et al. } \\
\text { (2016) }\end{array}$ \\
\hline & Plating (CFU/mL) & $\begin{array}{l}\text { Microaerobic } \\
\text { atmosphere, } \\
42{ }^{\circ} \mathrm{C} \text { for } 24 \mathrm{~h}\end{array}$ & $\begin{array}{l}\text { Wash, detach cells } \\
\text { (sonication), plate }\end{array}$ & $\begin{array}{l}\text { Polystyrene } \\
\text { microtiter } \\
\text { plates }\end{array}$ & Adhesion & $\begin{array}{l}\text { Šikić Pogačar } \\
\text { et al. (2016), } \\
\text { Trošt et al. } \\
(2016), \\
\text { Klančnik } \\
\text { et al. } \\
\text { (2017b) }\end{array}$ \\
\hline & Plating (CFU/mL) & $\begin{array}{l}\text { Aerobic } \\
\text { atmosphere, } \\
20 / 37^{\circ} \mathrm{C} \text { for } \\
24 / 48 \mathrm{~h} \text {; medium/ } \\
\text { chicken meat } \\
\text { juice }\end{array}$ & $\begin{array}{l}\text { Wash, detach cells } \\
\text { (glass beads), plate }\end{array}$ & $\begin{array}{l}\text { Polystyrene } \\
\text { microtiter } \\
\text { plates, } \\
\text { stainless steel } \\
\text { coupons }\end{array}$ & $\begin{array}{l}\text { Adhesion, } \\
\text { biofilm } \\
\text { formation }\end{array}$ & $\begin{array}{l}\text { Wagle et al. } \\
2019\end{array}$ \\
\hline \multirow[t]{2}{*}{$\begin{array}{l}\text { Viability of } \\
\text { adhered cells }\end{array}$} & BacTiterGlo kit & $\begin{array}{l}\text { Microaerobic } \\
\text { atmosphere, } \\
42{ }^{\circ} \mathrm{C} \text { for } 24 \mathrm{~h}\end{array}$ & $\begin{array}{c}\text { Wash, detach cells } \\
\text { (sonication), add } \\
\text { reagent, measure } \\
\text { bioluminescence }\end{array}$ & $\begin{array}{l}\text { Polystyrene } \\
\text { microtiter } \\
\text { plates }\end{array}$ & Adhesion & $\begin{array}{l}\text { Trošt et al. } \\
\text { (2016), } \\
\text { Klančnik } \\
\text { et al. } \\
(2017 \mathrm{~b})\end{array}$ \\
\hline & $\begin{array}{l}\text { 5-Cyano-2,3-ditolyl } \\
\text { tetrazolium chloride } \\
\text { (CTC) }\end{array}$ & $\begin{array}{l}\text { Microaerobic } \\
\text { atmosphere, } \\
37{ }^{\circ} \mathrm{C} \text { for } 48 \mathrm{~h}\end{array}$ & $\begin{array}{l}\text { Wash, detach cells, } \\
\text { CTC }(5 \mathrm{mM})\end{array}$ & $\begin{array}{l}\text { Polystyrene } \\
\text { microtiter } \\
\text { plates }\end{array}$ & $\begin{array}{l}\text { Biofilm } \\
\text { formation }\end{array}$ & $\begin{array}{l}\text { Duarte et al. } \\
\text { (2015) }\end{array}$ \\
\hline $\begin{array}{l}\text { DNA } \\
\text { quantification }\end{array}$ & $\begin{array}{l}\text { PCR-based (qPCR/ } \\
\text { dPCR) }\end{array}$ & $\begin{array}{l}\text { Microaerobic } \\
\text { atmosphere, } \\
42{ }^{\circ} \mathrm{C} \text { for } 24 \mathrm{~h} ; \\
\text { influence of } \\
\text { glucose levels, } \\
\text { monoculture/co- } \\
\text { culture with } \\
\text { Listeria } \\
\text { monocytogenes }\end{array}$ & $\begin{array}{l}\text { Wash, DNA isolation } \\
\text { from adhered cells }\end{array}$ & $\begin{array}{l}\text { Polystyrene } \\
\text { microtiter } \\
\text { plates, } \\
\text { stainless steel } \\
\text { coupons } \\
\text { (polished, } \\
\text { etched) }\end{array}$ & $\begin{array}{l}\operatorname{ccoN} \\
\text { sequence }\end{array}$ & $\begin{array}{l}\text { Klančnik et al. } \\
\text { (2018b) }\end{array}$ \\
\hline
\end{tabular}


Table 1 continued

\begin{tabular}{|c|c|c|c|c|c|c|}
\hline $\begin{array}{l}\text { Parameter } \\
\text { evaluated }\end{array}$ & Method & Conditions/work & Processing & Surface & Assay & References \\
\hline \multirow[t]{2}{*}{$\begin{array}{l}\text { Microscopy } \\
\text { techniques }\end{array}$} & $\begin{array}{l}\text { Confocal laser scanning } \\
\text { microscopy }\end{array}$ & $\begin{array}{l}\text { Aerobic/ } \\
\text { microaerobic } \\
\text { atmosphere, } \\
37 / 42{ }^{\circ} \mathrm{C} \text { for } \\
24 / 48 \mathrm{~h}\end{array}$ & $\begin{array}{l}\text { FilmTracer Live/Dead } \\
\text { Biofilm Viability kits } \\
\text { (SYTO-9, propidium } \\
\text { iodide); cyanine dye } \\
\text { (BOBO3); calcofluor } \\
\text { white dye }\end{array}$ & $\begin{array}{l}\text { Stainless steel } \\
\text { coupons, } \\
\text { Lab-Tek two- } \\
\text { chamber (no. } \\
\text { 1) } \\
\text { borosilicate } \\
\text { coverglass } \\
\text { system, } \\
\text { polystyrene }\end{array}$ & $\begin{array}{l}\text { Biofilm } \\
\text { formation }\end{array}$ & $\begin{array}{l}\text { Oh et al. } \\
\qquad \begin{array}{l}(2018), \\
\text { Wagle et al. } \\
(2019)\end{array}\end{array}$ \\
\hline & $\begin{array}{l}\text { Environmental } \\
\text { scanning electron } \\
\text { microscopy }\end{array}$ & $\begin{array}{l}\text { Aerobic } \\
\text { atmosphere, } \\
37^{\circ} \mathrm{C} \text { for } 48 \mathrm{~h}\end{array}$ & & $\begin{array}{l}\text { Stainless steel } \\
\text { coupons } \\
\text { Lab-Tek two- } \\
\text { chamber (no. } \\
\text { 1) } \\
\text { borosilicate } \\
\text { cover-glass } \\
\text { system, } \\
\text { polystyrene }\end{array}$ & $\begin{array}{l}\text { Biofilm } \\
\text { formation }\end{array}$ & $\begin{array}{l}\text { Wagle et al. } \\
\text { (2019) }\end{array}$ \\
\hline
\end{tabular}
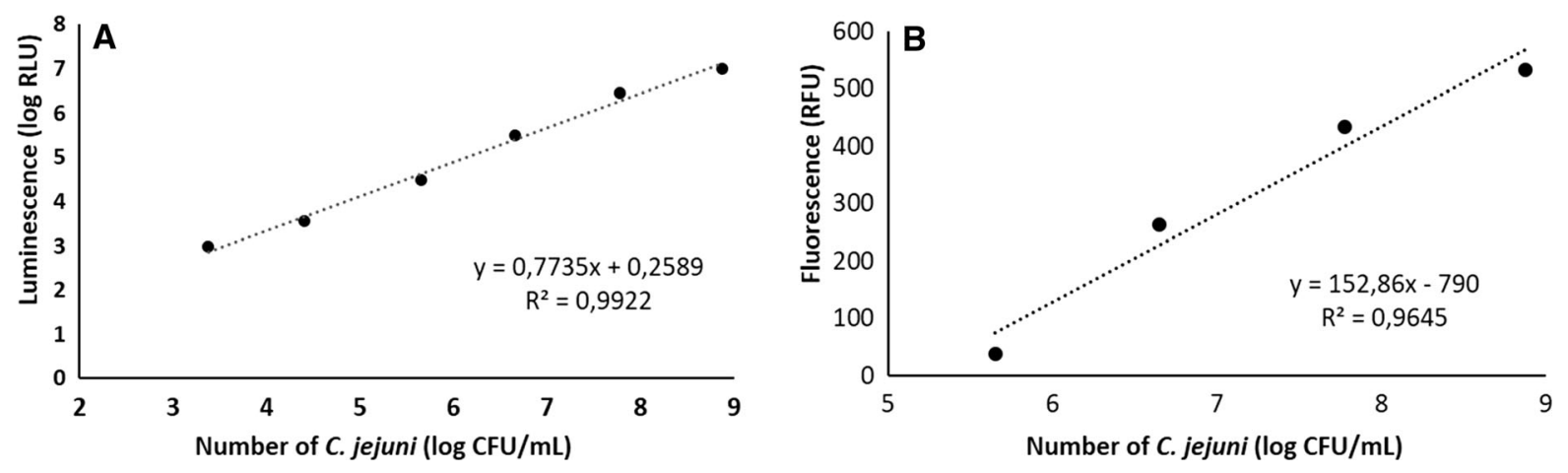

Fig. 2 Calibration curves for C. jejuni 11168 numbers with the addition of the BacTiterGlo reagent (a) and the resazurin reagent (b). RLU/RFU, relative luminescence/fluorescent units

to determine viable adhered cells after treatments with natural compounds: (1) spectrophotometric measurements for bioluminescence detection of ATP, using BacTiter-Glo assays (Klančnik et al. 2017b); and (2) absorbance measurements after using tetrazolium salts, as methyl tetrazolium chloride (Duarte et al. 2015).

For accurate determination of the anti-adhesion activity of a phytochemical, very low numbers of adhered viable cells have to be detected. Thus, for this review, we prepared some examples of calibration curves from overnight $C$. jejuni 11168 cultures for BacTiterGlo (Fig. 2a) and the resazurin reagent (Fig. 2b). These data clearly demonstrate that with BacTiterGlo the lower limit of detection is $\sim 3 \log$
$\mathrm{CFU} / \mathrm{mL}$, and this assay is thus better suited for detection of anti-adhesion, compared to the resazurin reagent, where the lower limit of detection is $>5 \mathrm{log}$ CFU. Thus, when the expected number of adhered cells was $<5 \log$ CFU, they were not detected with the resazurin reagent, but they were detected with BacTiterGlo. The main reason for this might be that the detection of cell viability with resazurin is based on the reduction of resazurin to fluorescent resorufin by the metabolically active cells, while with BacTiterGlo, the ATP in the cells is detected. As the metabolic activity of adhered cells can differ from that of their planktonic counterparts, the determination of adhered cells with resazurin and other such reagents 
based on the metabolic activity of the cells might be problematic and not accurate.

The quantification of adhesion and biofilm formation has thus relied on different approaches and techniques, which will lead to different evaluations for the adhered cells. Thus, for this review, we carried out an experiment using four different methods for determination of the anti-adhesion activities of some phytochemicals. The aim was to determine the antiadhesion activities of carvacrol and thymol using polystyrene microtiter plates according to four different methods. C. jejuni 11168 were prepared to an $\mathrm{OD}_{600}$ of 0.1 in Mueller-Hinton broth. The conditions were then without (control; in 1\% DMSO) and with addition of carvacrol and thymol at $0.25 \times \mathrm{MIC}$ (in $1 \%$ DMSO), in 96-well polystyrene microtiter plates (100 $\mu \mathrm{l} /$ well). After a $24-\mathrm{h}$ incubation at $42{ }^{\circ} \mathrm{C}$ under microaerobic conditions, the plates were washed three times with PBS, and where appropriate, treated for $5 \mathrm{~min}$ in an ultrasonic bath $(2,3$, and 4$)$. The levels of adhesion were then determined, as follows:

1. Quantification of the adhered cell biomass using crystal violet staining, as described by Klančnik et al. (2017b);

2. Direct quantification of the adhered cells using serial dilutions and plating on Mueller-Hinton agar, as CFU/well (Klančnik et al. 2017b);

3. Quantification of adhesion using BacTiterGlo and measurement of the luminescence signal, as described by Klančnik et al. (2017b);

4. Quantification of adhered cells using $100 \mu \mathrm{l}$ resazurin reagent per well with measurement of excitation and emission fluorescence at $560 \mathrm{~nm}$ and $590 \mathrm{~nm}$, adapted method which was previously described by Kovač et al. (2015) for MIC determination.

These data of the anti-adhesion activities of carvacrol and thymol are presented in Fig. 3. As the four assays provide different types of information, the ratio of crystal violet will indicate the biomass of the adhered cells. These data show no significant differences between the biomass of the adhered $C$. jejuni cells of untreated control and those treated with carvacrol and thymol (Fig. 3a). The reason for this might be that in the first $24 \mathrm{~h}, C$. jejuni have less possibility to form strong biofilms. As previously reported, adhesion of $C$. jejuni to polystyrene is strain dependent (Bronnec et al. 2016), and more than $24 \mathrm{~h}$ is needed to form adequate biomass (Melo et al. 2017; Klančnik et al. 2017b). However, the ability of $C$. jejuni to adhere strongly is increased under conditions similar to those in the avian industry (e.g., in chicken juice). The nutritive particles available in chicken juice can form a conditioning layer on polystyrene and glass surfaces, which can facilitate bacterial adhesion. Thus, only $4 \mathrm{~h}$ of incubation was sufficient for the initial establishment of the biofilm structure, and this is why Camplyobacter spp. act as a constant source of contamination in the food industry (Schluter et al. 2015; Melo et al. 2017).

Furthermore, the data in Fig. $3 \mathrm{~b}$ show that using the direct method of colony counting, there appeared to be significantly fewer adhered cells on the polystyrene when treated with both carvacrol and thymol. The adhesion of the untreated control $C$. jejuni to the polystyrene surface of microtiter plates was $6.77 \pm 0.40 \log \mathrm{CFU} /$ well. The greater reduction was seen for adhesion of $C$. jejuni in the presence of thymol, to $4.19 \pm 0.76 \log \mathrm{CFU} /$ well, which represented $38 \%$ inhibition of $C$. jejuni adhesion. Significant anti-adhesion effects were also seen for carvacrol, as $7.70 \pm 0.70 \log \mathrm{CFU} /$ well, which represented $31 \%$ inhibition of $C$. jejuni adhesion.

Interestingly, these findings were not confirmed with the methods here that measured the presence of ATP, as representative of the metabolic activity of the adhered cells. With BacTiterGlo, the anti-adhesion effect of thymol was again significant, although carvacrol showed no anti-adhesion effect (Fig. 3c). This difference in these data for the direct counting and the BacTiterGlo analysis for carvacrol can be explained by the presence of $C$. jejuni as VBNC, which cannot be detected by the cultivability assay, but are detectable using BacTiterGlo. Additionally, for this review, we used the calibration curve from Fig. 2a to quantify the numbers of metabolically active cells, to define them as $\log \mathrm{CFU} / \mathrm{mL}$. These data for the adhesion of the untreated control $C$. jejuni to the polystyrene surface of the microtiter plates was $6.93 \pm 1.56 \log \mathrm{CFU} / \mathrm{mL}$. Again, here the only significant reduction seen for adhesion of $C$. jejuni was with thymol, down to $5.23 \pm 1.31 \log \mathrm{CFU} / \mathrm{mL}$, which represented $25 \%$ inhibition of $C$. jejuni adhesion. The differences obtained for the anti-adhesion effects of carvacrol potentially confirm the presence of the VBNC form of $C$. jejuni as a response to this stress condition. On the other hand, for the anti-adhesion 

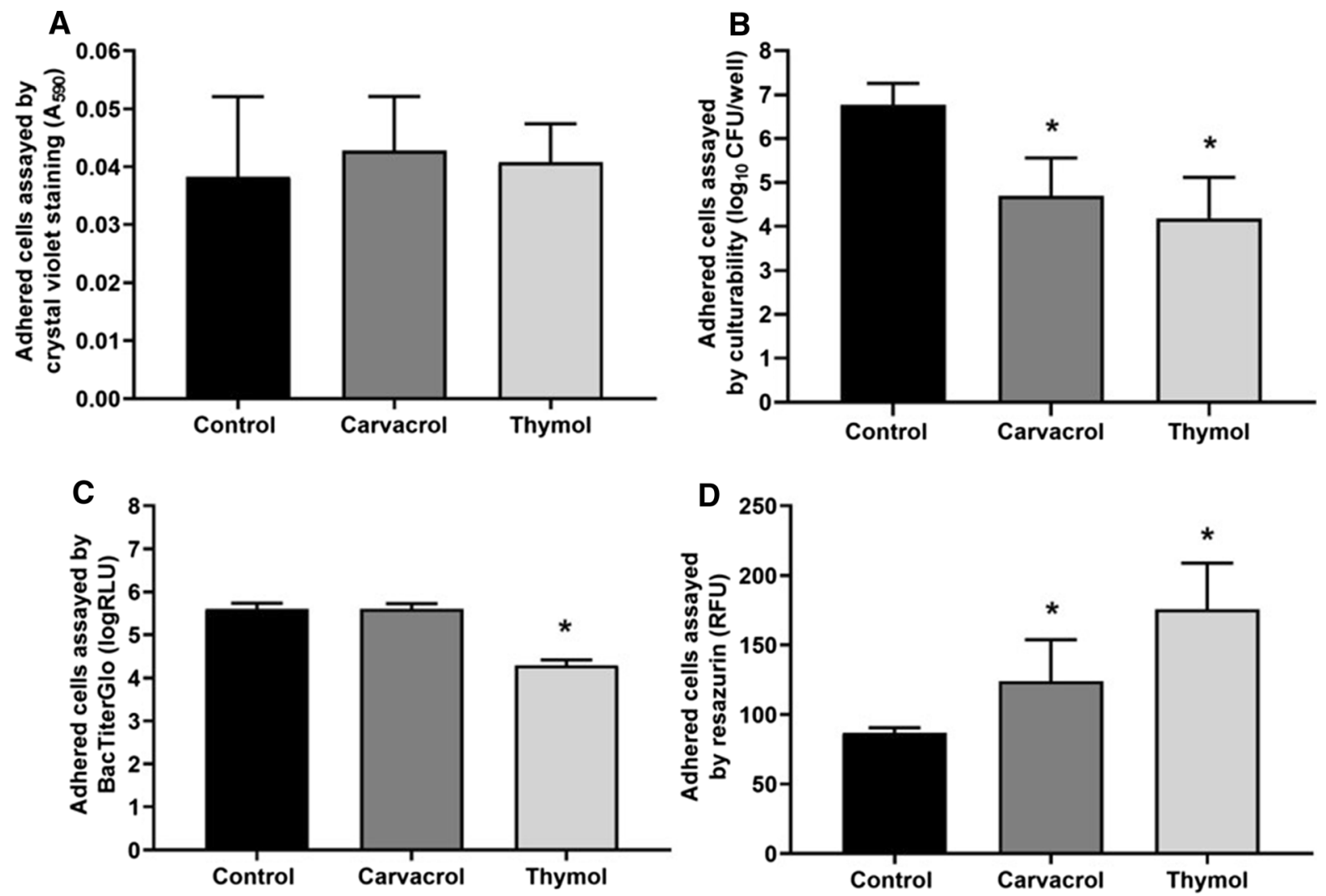

Fig. 3 Anti-adhesion activities against C. jejuni NCTC 11168 (on polystyrene microtiter plates) for carvacrol $(0.25 \times$ MIC) and thymol $(0.25 \times \mathrm{MIC})$, as compared to the untreated controls. a Quantification with crystal violet staining and $\mathrm{A}_{590}$ measures. b Direct quantification of cultivable cells, as $\log _{10}$

data obtained with the methods that used the resazurin reagent, which is reduced to the highly fluorescent resorufin in proportion to the metabolic activity of a cell population, these were not comparable with the methods using BacTiterGlo (Fig. 3c, d). Additionally, it should be noted that all of these data, even for the control, were around the limit of detection for the resazurin reagent (5 log units; see also above), which means that the resazurin quantification will be less accurate.

On the basis that it is known that Campylobacter spp. can attach to food contact surfaces, to represent an important hazard for safe food production, and that their clinical importance is based on their formation of biofilms, it is surprising that there is no standard method already defined to determine the numbers of adhered cells. Besides the commonly used method to quantify biofilm mass according to culturable cell

CFU/well. c Quantification with BacTiterGlo, as relative luminescent units (log RLU). d Quantification using the resazurin agent, as relative fluorescent units (RFU). *, $p<0.05$, versus relevant control (Student's t-tests)

numbers, there is no simple method to determine the viability of the adhered cells, which is needed for effective control of biofilm systems. These data provided here suggest that anti-adhesion research should include at least two methods to analyse adhered cells, one being the culturable counts by the plate method, and the alternative measurement being the viability or metabolic activity of the bacteria, such as used with the dyes in BacTiterGlo.

Recently, PCR-based methods have been used as a novel approach for adhesion assays and in biofilm research (Winkelströter et al. 2014; Klančnik et al. 2018b). Quantitative real-time PCR (qPCR) has been introduced to detect low levels of DNA, as a rapid, accurate, sensitive and specific method for detection and quantification of adhered $C$. jejuni cells directly from the microtiter plates. Additionally, qPCR takes into account $C$. jejuni that are VBNC, which might not 
be considered using the plate counting methods. We can highlight that these studies have used the newer technology to optimise these analyses, such as digital PCR and qPCR, with the construction of standard curves for quantification. Briefly, Klančnik et al. (2018b) used a $C$. jejuni DNA mix from 14 C. jejuni strains for digital PCR quantification, with the standard curve created with serial dilutions using qPCR detection of specific sequences of $c c o N$ (Toplak et al. 2012). The standard curve was calculated from the $C_{t}$ values and the corresponding DNA copy numbers (Klančnik et al. 2018b). This is the only study that has used this novel approach of PCR-based methods for quantification of adherent $C$. jejuni in monospecies biofilms, and also as multispecies biofilms, with the anti-adhesion determinations using polystyrene and sterile polished and etched stainless-steel coupons (Klančnik et al. 2018b).

Different microscopy techniques have also been used for direct determination of numbers of cells attached to an abiotic surface or formed into a biofilm (Asakura et al. 2007; Wagle et al. 2019). The formation of biofilms can also be assessing according to EPS production, using fluorescence microscopy, where the biofilms can be stained as follows (Oh et al. 2018):

1. SYTO 9 This dye has a high affinity for DNA, and is used to detect total DNA (both intracellular and extracellular);

2. BOBO-3 This is an intercalative DNA-binding red fluorescent dye, and as it cannot penetrate through membranes, it is used to detect extracellular DNA;

3. Calcofluor white This fluorescent dye binds to $\beta 1-3$ and $\beta 1-4$ carbohydrate linkages of polysaccharides, and it has been used to detect extracellular polysaccharides in C. jejuni biofilms.

Electron microscopy is also an important method to examine bacterial adhesion patterns and biofilm formation (Chae and Schraft 2000; Hazelton and Gelderblom 2003; Golding et al. 2016). Scanning electron microscopy provides micrographs of surfaces, and has often been the method of choice to study bacterial adhesion and biofilm characteristics (Gomes and Mergulhão 2017). Wagle et al. (2019) used environmental scanning electron microscopy to validate the influence of phytochemicals on mature biofilms of $C$. jejuni formed on stainless-steel coupons and borosilicate covers. They followed the biofilm architecture and the modulation of the biofilm structure or loss of EPS after treatments with transcinnamaldehyde, eugenol and carvacrol.

Confocal laser scanning microscopy is useful to study the viability of adhered $C$. jejuni cells, as well as to study the architecture and viability of $C$. jejuni biofilms (Asakura et al. 2007; Wagle et al. 2019). The viability of $C$. jejuni cells in a biofilm is often determined using Live/Dead Viability kits (Molecular Probes, Eugene, OR, USA), where two fluorescent dyes used allows differentiation of live from dead cells: SYTO 9 and propidium iodide (Asakura et al. 2007; Wagle et al. 2019).

Although microscopy is an important method to examine the adhesion patterns of $C$. jejuni to abiotic surfaces and the effects of phytochemicals, standard methods for the use of scanning electron microscopy and confocal laser scanning microscopy have not yet been described. Wagle et al. (2019) showed that three plant secondary metabolites, trans-cinnamaldehyde, carvacrol and eugenol, were effective for reduction of C. jejuni mature biofilm formation and inactivation of mature biofilms on polystyrene and stainless-steel surfaces. They used confocal laser scanning microscopy in combination with differential staining of live and dead cells by Live/Dead Biofilm Viability Kit in which SYTO-9 and propidium iodide stains were used. They show that after 10 min of treatment, the treated samples were red indicating inactive cells and the cells in the control sample were green indicating active cells. This pointed towards strong anti-biofilm effects of these plant secondary metabolites.

\section{Anti-adhesion and anti-biofilm compounds of natural origin}

The activities of extracts of plants, mushrooms, essential oils and isolated compounds, for inhibition of adhesion and biofilm formation by $C$. jejuni on abiotic surfaces has become of increasing interest over the last few years. A summary of the data that have been reported for plant and mushroom extracts, and for extracts of waste materials from essential oil and plant food production, is presented in Table 2, along with the data for various fractions from plant extracts. Also, similar studies with pure compounds are summarised in Table 3. The structures of the most commonly identified compounds that show anti-adhesive and 


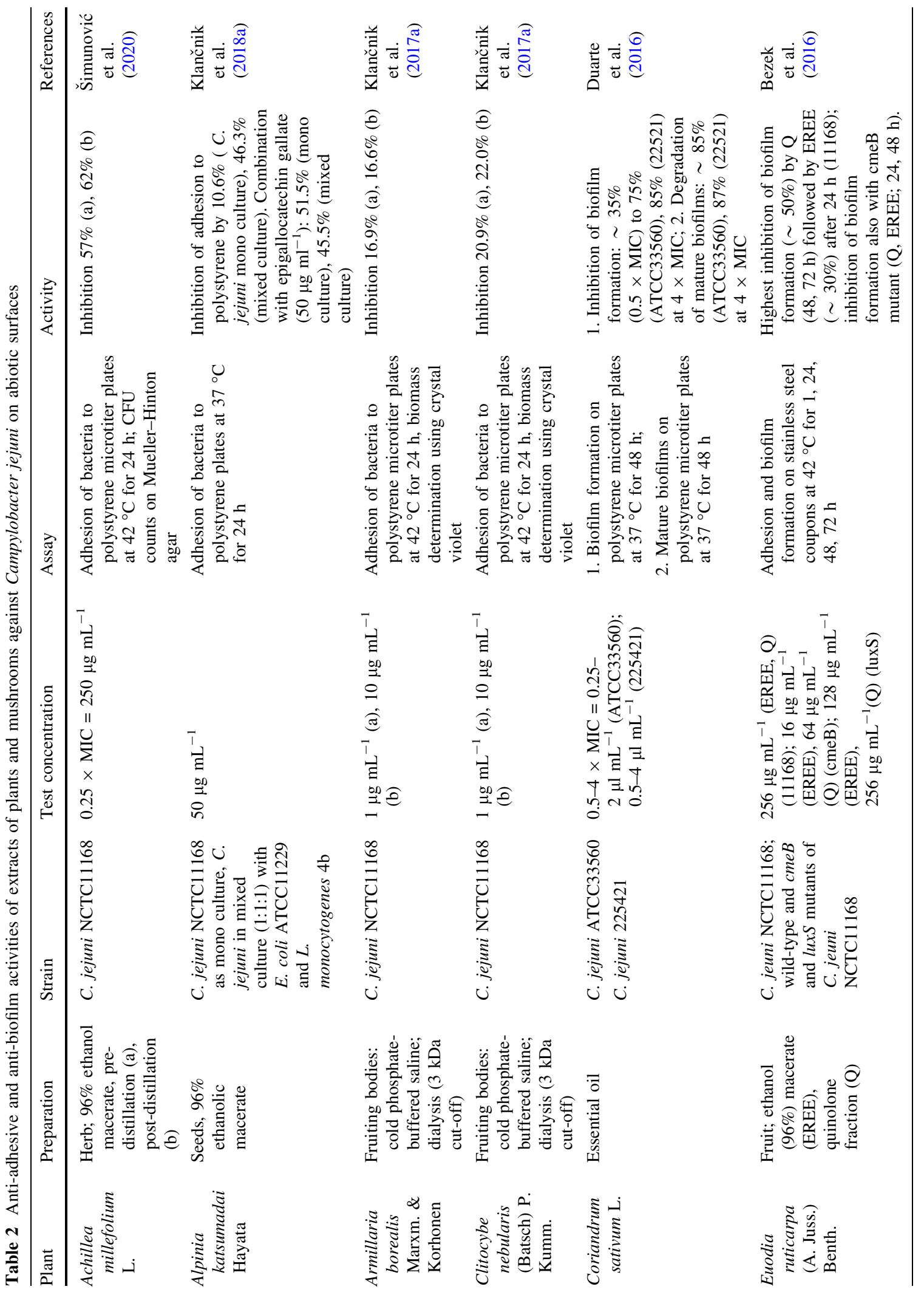




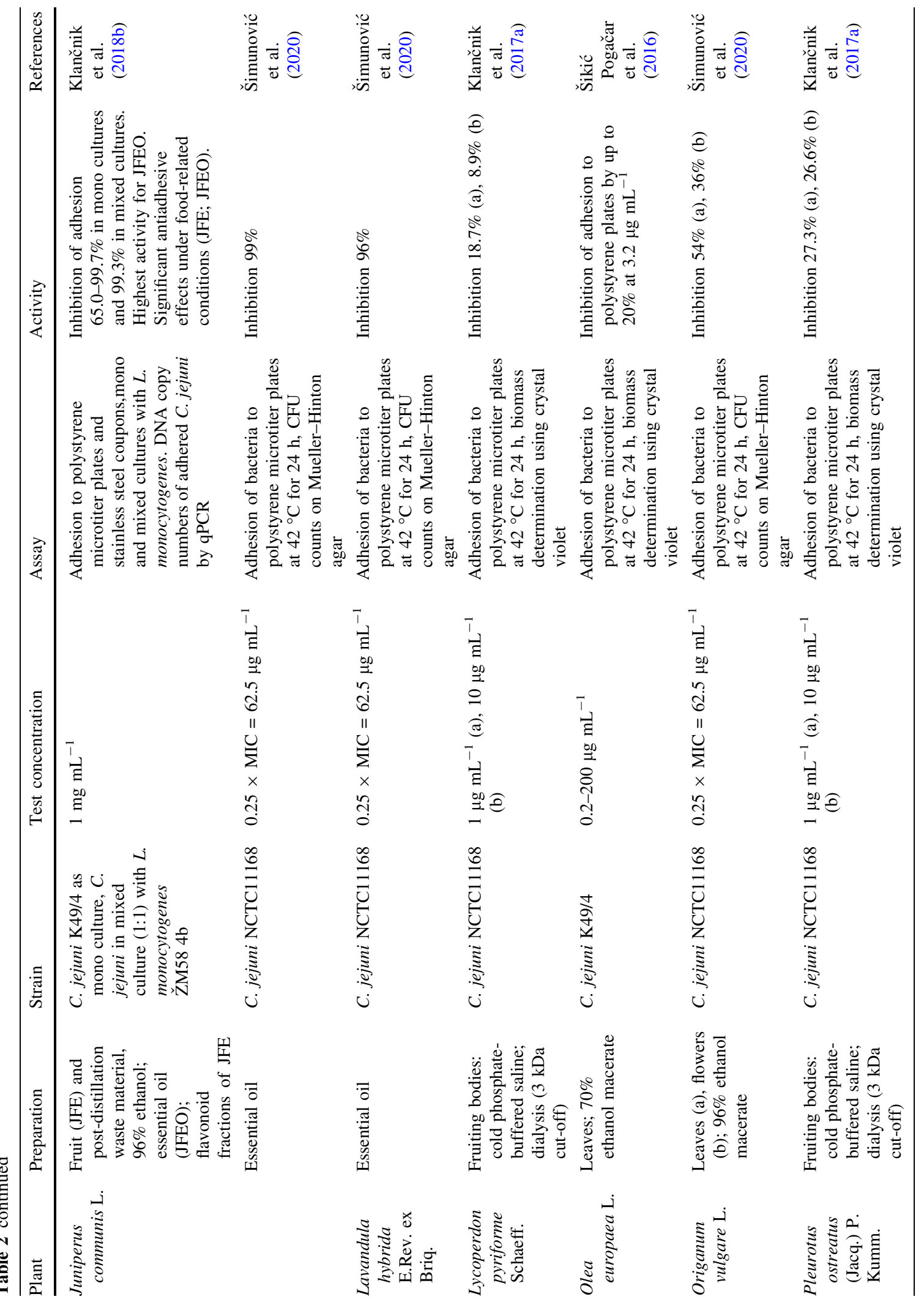




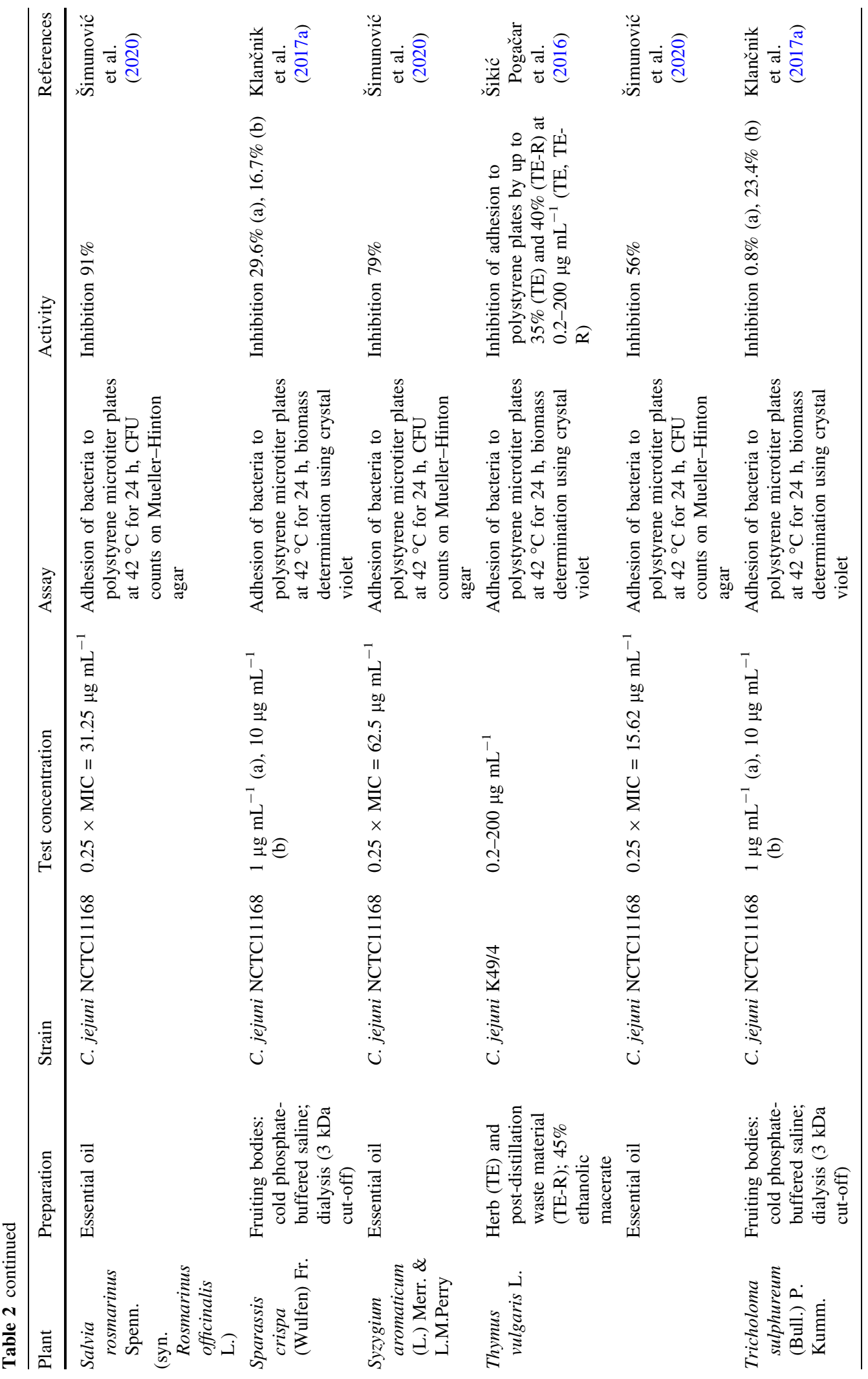




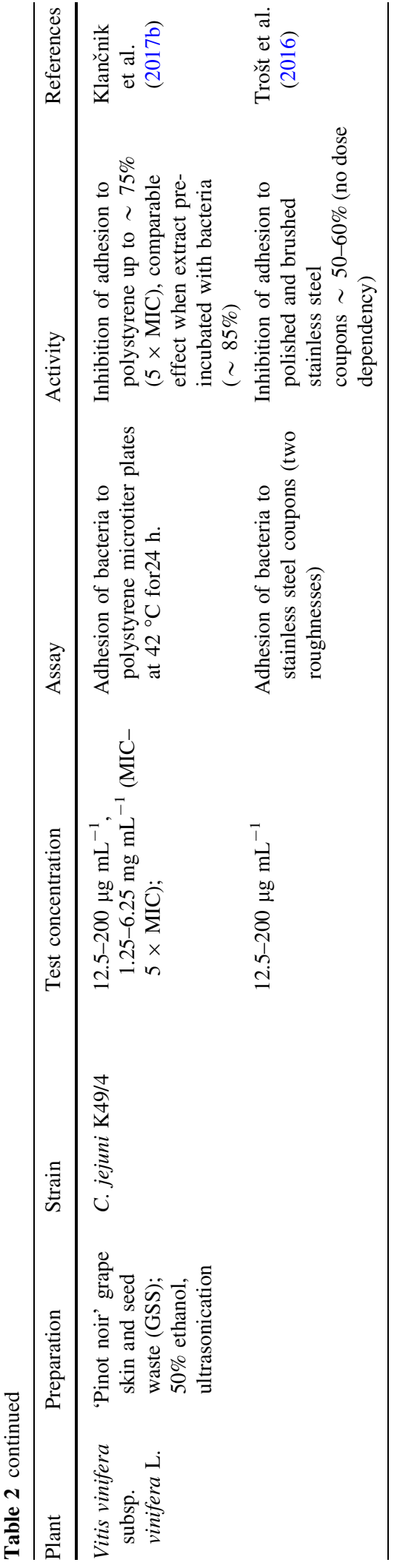

anti-biofilm effects against $C$. jejuni when exposed to abiotic surfaces are presented in Fig. 4.

Extracts prepared from the fruiting bodies of 21 wild basidiomycete mushrooms and cultivated oyster mushroom (Pleurotus ostreatus) have shown different anti-adhesion effects against $C$. jejuni on polystyrene surfaces (Klančnik et al. 2017a). The highest activities were seen for Sparassis crispa and P. ostreatus aqueous extracts, with $\sim 30 \%$ and $27 \%$ inhibition, respectively, although no dose dependency was seen for the comparison of $1 \mu \mathrm{g} / \mathrm{mL}$ and $10 \mu \mathrm{g} / \mathrm{mL}$ extract concentrations. The only extract that showed increased activity at higher concentrations and inhibition of $>20 \%$ was prepared from Tricholoma sulphureum. However, this type of material needs to be further investigated for anti-adhesive activities, considering also the low concentrations at which some extracts have shown remarkable potential.

Similar anti-adhesive potential at low concentrations $(0.2-200 \mu \mathrm{g} / \mathrm{mL})$ have been reported for extracts of the herb Thymus vulgaris, and for the material that remains after hydrodistillation of its essential oils (Šikić Pogačar et al. 2016). Indeed, the hydrodistillation waste material was active at $0.2 \mu \mathrm{g} / \mathrm{mL}$, although as for the mushroom extracts, no clear dose dependency was seen, except for no anti-adhesive effects at the lowest concentration of the thyme herbal extract. As the hydrodistillation waste material showed an even higher activity than the crude herbal extract, the essential oil produced can be excluded as an effective ingredient in these thyme preparations. However, for carvacrol, which is a phenolic monoterpene that occurs at high proportions in thyme oils, significant inhibition of biofilm formation on polystyrene and on stainless steel coupons has been shown, along with reduction of mature biofilms (Šimunović et al. 2020; Wagle et al. 2019). Quantification of major phenolic compounds in the two thyme extracts recently reported by Šimunović et al. (2020) and Wagle et al. (2019) showed higher levels of 7-O-glucuronides of luteolin and apigenin in the waste material $(4.0 \%$, $1.0 \%$, respectively) than in the crude herbal extract $(3.7 \%, 0.8 \%)$, but lower levels of rosmarinic acid $(5.1 \%, 5.6 \%)$ and $3^{\prime}-\mathrm{O}-\left(8^{\prime \prime}-\mathrm{Z}\right.$-caffeoyl) rosmarinic acid $(3.0 \%, 3.1 \%)$. Here, rosmarinic acid showed no significant anti-adhesion effects (Šimunović et al. 2020), and therefore further investigations are needed to evaluate the role of flavone glycosides as antiadhesives against $C$. jejuni. This is also supported by a 


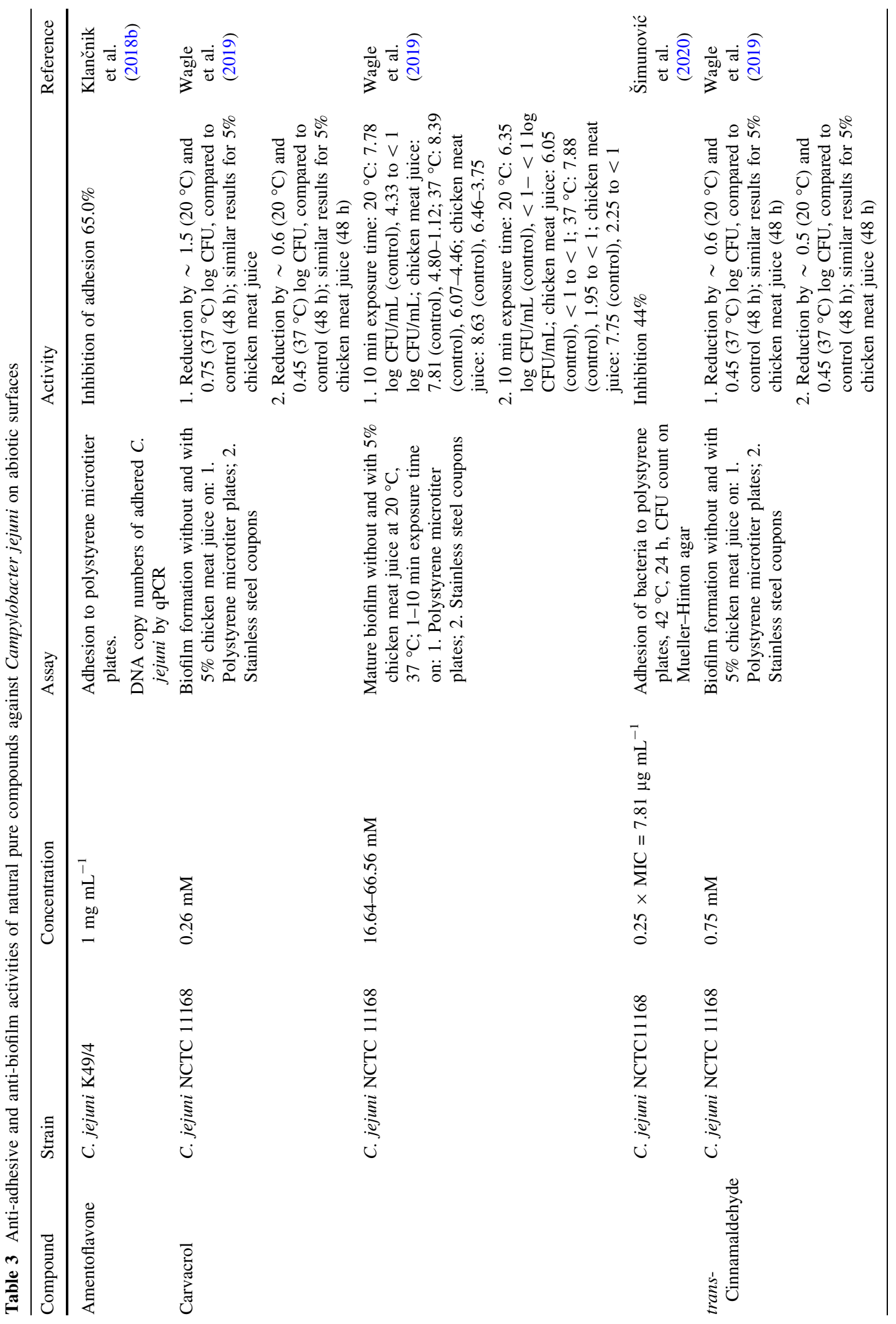




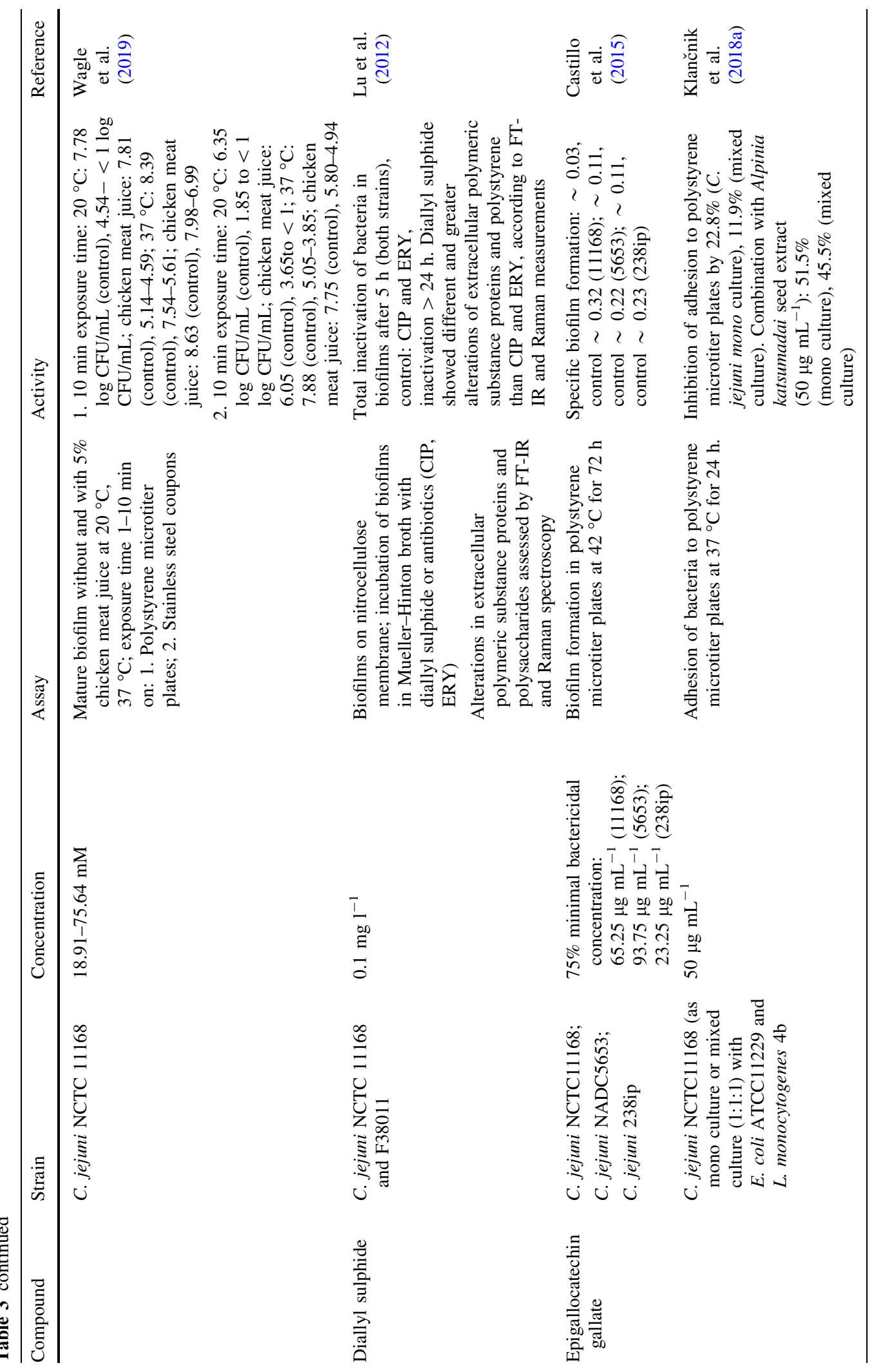




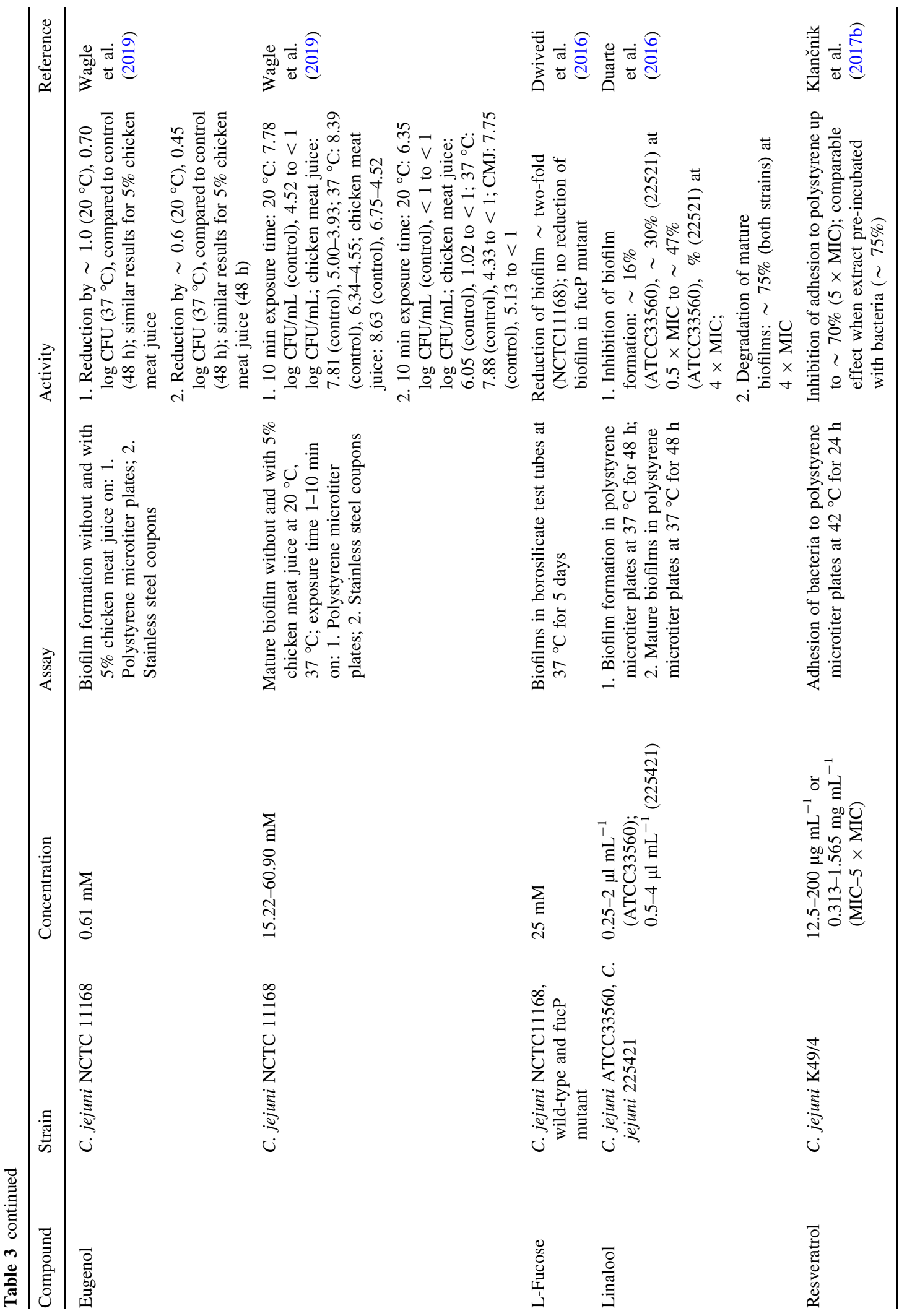




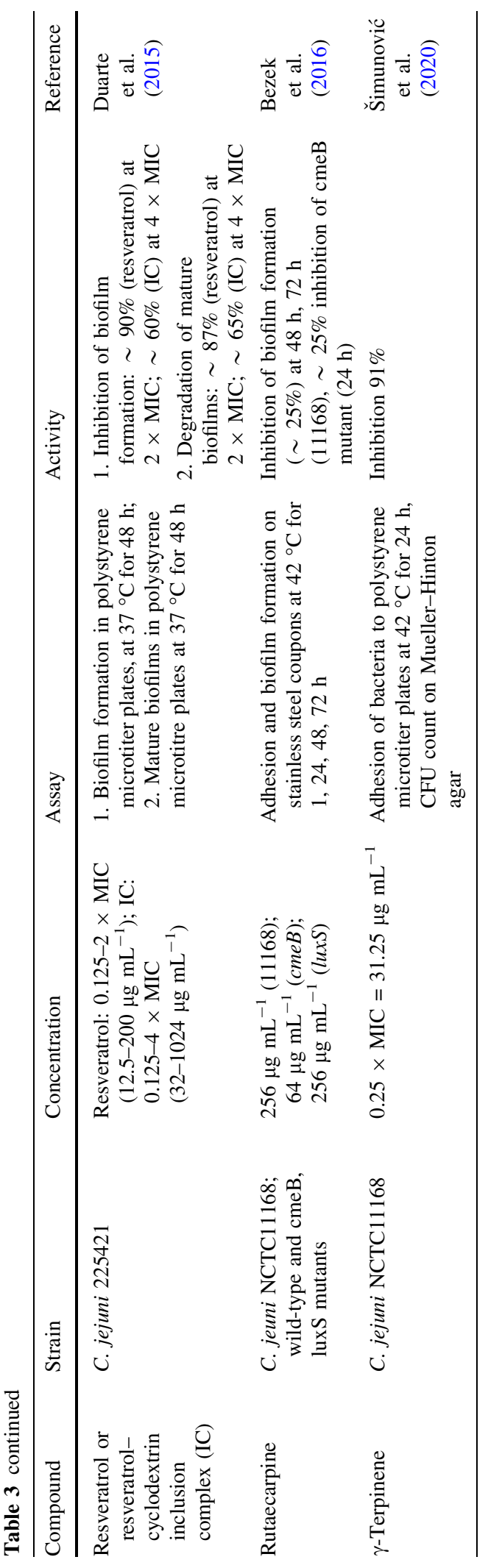

study of two flavonoid-rich fractions from juniper pseudo-fruits (Juniper communis), which showed inhibition of $C$. jejuni attachment to polystyrene of $\sim 70 \%$. The flavonoid fractions differed in their compositions for flavone glycosides and biflavones, where the biflavonoid amentoflavone showed the lowest activity, with about $60 \%$ inhibition.

Consideration of the data summarised in Tables 2 and 3 shows that phenolic compounds other than the flavonoids might also have major roles in these antiadhesive effects against $C$. jejuni. This is exemplified by olive (Olea europaea) leaf extracts, which are rich in oleuropein, a secoiridoid that is esterified with the phenylethanol derivative hydroxytyrosol. Oleuropein, the phenylethanoid verbascoside, and luteolin-7-Oglucoside were reported to be major compounds in an olive leaf extract tested by Šikić Pogačar et al. (2016), at $18.9 \%, 1.1 \%$ and $2.9 \%$, respectively. This olive leaf extract inhibited adhesion of $C$. jejuni to polystyrene even at the low concentration of $3.5 \mu \mathrm{g} / \mathrm{mL}$. Analysis of the different phenolic fractions in a $50 \%$ ethanolic extract of skins and seeds from the 'Pinot noir' grape (Vitis vinfera) that inhibited adhesion of $C$. jejuni to polystyrene and stainless steel coupons by $50 \%$ to $60 \%$ revealed (per kilogram plant material) $0.4 \mathrm{~g}$ total flavonoids, $12.4 \mathrm{~g}$ total catechins, $1.27 \mathrm{~g}$ total anthocyanidins and $0.04 \mathrm{~g}$ total hydroxycinnamic acids (Trošt et al. 2016). However, the mode of action of this extract has not been clarified yet, and non-specific binding to the bacteria might be responsible for these activities, as no dose dependency was seen. More detailed studies with distinct fractions, or with the isolated pure compounds, from the various phenolic classes found in grapes is thus still needed.

Also for grapes, the stilbene resveratrol has been tested both as the pure compound (Duarte et al. 2015; Klančnik et al. 2017b) and as an inclusion complex with hydroxypropyl- $\gamma$-cyclodextrin, which improves the water solubility of resveratrol (Duarte et al. 2015). Good inhibition was seen here for $C$. jejuni biofilm formation and for detachment of mature $C$. jejuni biofilms from polystyrene surfaces, although at concentrations greater than the MICs. Duarte et al. (2015) concluded that the anti-biofilm effects of resveratrol are associated with regulation of biofilm-related genes, including those involved in QS. On the other hand, morphological changes induced by resveratrol were reported for $C$. jejuni cells by Klančnik et al. (2017b), with the transformation of spiral cells into 
<smiles>O=c1cc(-c2ccc(O)c(-c3c(O)cc(O)c4c(=O)cc(-c5ccc(O)cc5)oc34)c2)oc2cc(O)cc(O)c12</smiles>

Amentoflavone<smiles>Cc1ccc(C(C)C)cc1O</smiles>

Carvacrol<smiles>O=C/C=C/c1ccccc1</smiles>

trans-Cinnamaldehyde<smiles>O=C(O[C@H]1Cc2c(O)cc(O)cc2O[C@H]1c1cc(O)c(O)c(O)c1)c1cc(O)c(O)c(O)c1</smiles>

Epigallocatechin gallate<smiles>C=CCCc1ccc(O)c(OC)c1</smiles>

Eugenol<smiles>Oc1ccc(/C=C/c2cc(O)cc(O)c2)cc1</smiles>

Resveratrol<smiles>CCCC/C=C\CCCCCCCc1cc(=O)c2ccccc2n1C</smiles><smiles>O=c1c2ccccc2nc2n1CCc1c-2[nH]c2ccccc12</smiles>

Rutaecarpine<smiles>CC1=CCC(C(C)C)=CC1</smiles>

-Terpinene<smiles>C=CC(C)(O)CCC=C(C)C</smiles>

Linalool

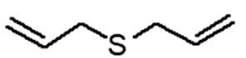

Diallyl sulfide

Fig. 4 Structures of compounds that show anti-adhesive or anti-biofilm activities against $C$. jejuni exposed to abiotic surfaces

non-spiral or short bacillary forms, without pits and flagella. The same effects as these seen for resveratrol were also reported for their 'Pinot noir' extract.

As an example of alkaloids with anti-biofilm activities against $C$. jejuni, interesting data have been reported for an extract of Euodia rutaecarpa fruit (also known as Tetradium ruticarpum), a quinolone-rich fraction from this extract, and its isolated rutaecarpine, an indoloquinazoline alkaloid (Bezek et al. 2016). These compounds have shown promising antimicrobial effects (Pan et al. 2014; Wang et al. 2013). The greatest inhibition of biofilm formation seen here for stainless steel coupons was obtained for a complex mixture of structurally closely related 2-alkyl-4quinolones, which included evocarpine as its major component (42\%). This study by Bezek et al. (2016) went beyond the phenomenological approach to measure reduction of $C$. jejuni biomass on abiotic surfaces, by studying also the influence of these compounds on efflux pumps. They investigated the
CmeABC pump in particular, using a $c m e B$ knock-out mutant, as well as QS, using the reporter strain Vibrio harveyi $\mathrm{BB} 170$ to measure autoinducer-2 (AI-2) levels. It has been shown previously that AI-2 has an important role in biofilm development of $C$. jejuni (Reeser et al. 2007). As the LuxS homologous protein is known to be responsible for AI-2 biosynthesis (Elvers and Park 2002), a luxS knock-out mutant was also included in these studies of the Euodia alkaloids. However, no significant differences were seen for biofilm inhibition between the wild-type and the luxS mutant, with no correlation seen between AI-2 levels in the wild-type or the $c m e B$ mutant and the CFU on stainless steel coupons (Bezek et al. 2016). Interestingly, in a previous study of the antimycobacterial activities of a hexane extract of E. rutaecarpa, evocarpine, and the indoloquinazolines evodiamine and rutaecarpine, antagonistic actions were seen for evodiamine and rutaecarpine on the effects of evocarpine, which were most likely due to their formation 
of a complex in solution (Hochfellner et al. 2015). Hence, such interactions cannot be excluded when plant extracts or multicomponent fractions are studied.

Under food-related conditions, $C$. jejuni will not be expected to just form pure biofilms, as mixed cultures of C. jejuni with E. coli and Listeria monocytogenes can occur. On this basis, the data from a study of an ethanolic extract of the seeds ('grains of paradise') of Alpinia katsumadai, a plant of the ginger family, are of interest, as this showed greater biofilm inhibition for mixed cultures. This ethanolic extract of A. katsumadai seeds was shown to be rich in diarylheptanoids (1,7-diphenyl-4,6-heptadien-3-one, 12.9\%) and flavanones (pinocembrin, 9.5\%; alpinetin, $5.7 \%$ ). Combining this extract with the phytochemical epigallogatechin gallate (EGCG) also increased this effect (Klančnik et al. 2018a). EGCG itself has also shown activity at concentrations below its minimal bactericidal concentration under two different conditions $\left(42{ }^{\circ} \mathrm{C}, 72 \mathrm{~h} ; 37^{\circ} \mathrm{C}, 24 \mathrm{~h}\right)$, as reported by Castillo et al. (2015) and Klančnik et al. (2018a), respectively.

As adhesion and biofilm formation of $C$. jejuni on abiotic and biotic surfaces involves highly glycosylated structures like flagellins (Sulaeman et al. 2012; Schmidt et al. 2019), it is not surprising that carbohydrates have been shown to interfere with biofilm formation on abiotic surfaces. L-Fucose at $25 \mathrm{mM}$ can reduce biofilm formation on borosilicate surfaces by about $50 \%$, compared to the control (i.e., growth media without L-fucose), whereas biofilm formation of a fucP mutant was similar to that of the wild-type control (Dwivedi et al. 2016). The $f u c P$ gene encodes the fucose permease protein, which is essential for fucose uptake from the extracellular medium $(\mathrm{Mu}-$ raoka and Zhang 2011). These data for the measurements of bacterial biomass using crystal violet staining were in agreement with the analysis by scanning electron microscopy, which showed greatly reduced biofilm formation on borosilicate glass in the samples with L-fucose (Dwivedi et al. 2016).

Overall, the most intensively investigated phytochemicals are those of the essential oils and their individual constituents. Remarkable anti-adhesive effects have been reported for juniper essential oil and an ethanolic extract, with $>90 \%$ inhibition at $1 \mathrm{mg} / \mathrm{mL}$ (Klančnik et al. 2018b). These materials showed large anti-adhesive effects on C. jejuni for stainless-steel coupons with different surfaces, and with $C$. jejuni as individual cultures or as biofilms of mixed cultures with L. monocytogenes (Klančnik et al. 2018b). Large anti-adhesive effects of juniper essential oil have also been seen against $C$. jejuni for adhesion to polystyrene plates, at $62.5 \mu \mathrm{g} / \mathrm{mL}$ as $0.25 \times$ MIC (Šimunović et al. 2020), which indicates that this juniper essential oil includes potent antiadhesives. Essential oils of lavender (Lavandula hybrida), rosemary (Salvia rosmarinus) and clove (Syzygium aromaticum) have also been shown to reduce $C$. jejuni adhesion to polystyrene plates by $\sim 80 \%$ (clove), and even by $>90 \%$ (lavender, rosemary) at concentrations that are clearly below their respective MICs (i.e., $0.25 \times$ MIC). The major compounds contained in clove oil (i.e., eugenol) and lavender oil (i.e., linalool) have also shown inhibitory effects on biofilm formation and on mature biofilms (Duarte et al. 2016; Wagle et al. 2019). Of note, however, although it might be tempting to use the effects of such individual constituents to directly define the activities of the essential oils, the effects of essential oils will rather be the results of the concerted actions of a number of their individual constituents.

Environmental scanning electron microscopy and confocal laser scanning microscopy have also been used to investigate the effects of trans-cinnamaldehyde, eugenol and carvacrol on $C$. jejuni biofilm architecture and viability on stainless steel coupons. After treatments for only $10 \mathrm{~min}$, most of the EPS in the biofilms were lost, and the majority of the $C$. jejuni cells were dead. Interestingly, trans-cinnamaldehyde significantly down-regulated genes related to cell motility, and eugenol and carvacrol also modulated the expression of genes related to cell motility, surface modifications, stress responses and QS. Alterations were also seen at the proteome level, with upregulation of the flagellar protein, cytochrome c553, and the putative peptidyl-prolyl cis-isomerase, and down-regulation of the periplasmatic nitrate reductase, chaperones and bacterioferritin (Wagle et al. 2019).

Linalool is also a prominent constituent of coriander oil, which has shown activity against mature biofilms of $C$. jejuni on stainless steel coupons, although only at concentrations well in excess of its MIC (i.e., $4 \times$ MIC). Linalool and coriander essential oil were also studied for their effects on QS using a disc diffusion assay with the Chromobacterium violaceum biosensor strain, and on the QS-dependent 
production of violacein. At the more relevant lower concentrations of $0.1 \mu \mathrm{L} / \mathrm{mL}$, the anti-QS effects of linalool were more pronounced than those of coriander oil, with $70 \%$ and $43 \%$ inhibition, respectively (Duarte et al. 2016).

Alterations to $C$. jejuni membrane permeability have also been reported for $\alpha$-pinene at concentrations well below its MIC, which is a monoterpene hydrocarbon that has been defined as a constituent of many essential oils (Kovač et al. 2015). Indeed, scanning electron micrographs of E. coli, Staphylococcus aureus and Bacillus subtilis treated with essential oil combinations have clearly shown deformation, permeabilisation and disruption of bacterial cell walls ( $\mathrm{Lv}$ et al. 2011). Hence, morphological changes to the bacterial cell wall might represent a mechanism for these anti-adhesive effects. Therefore, further investigations of essential oils and their individual constituents on the membrane structures responsible for specific adhesion to abiotic surfaces are needed.

One of the most promising phytochemicals at present appears to be diallyl sulphide, which is a major constituent of processed garlic (Allium sativum), including black garlic (Yang et al. 2019). The antimicrobial activities of garlic have been referred to its organosulphur compounds, as shown by changes in the bacterial cell membrane components using Fourier-transform infrared and Raman spectroscopy (Lu et al. 2011). The low concentration of $0.1 \mu \mathrm{g} / \mathrm{mL}$ of a garlic concentrate showed total inactivation of $C$. jeuni adhesion in biofilms on nitrocellulose membranes. Decay of the EPS matrix of these $C$. jejuni biofilms was seen within $1 \mathrm{~h}$ of the treatment with diallyl sulphide, followed by the destruction of cell integrity, as also seen for planktonic cells (Lu et al. 2012). Hence, it appears that organosulphur compounds represent a still underexplored source of anti-biofilm compounds of natural origin, and thus these should gain more attention in future studies.

\section{Adhesion mechanisms and identification of targets against adhesion of $C$. jejuni}

Campylobacter have developed a multiplicity of adhesion mechanisms. As is known, their attachment takes place in two phases: (1) the initial physical reversible phase that is mediated by van der Waals and electrostatic interactions; and (2) the irreversible phase that is mediated by the bacterial surface structures (e.g., flagella, polysaccharides), which potentially bridge the bacterial cell and the attachment surface, to overcome the energy barrier established by the negative charges of the bacterial cell and attachment surface (Nguyen et al. 2012). A number of further cell properties are also involved, such as cell morphology, membranes, membrane proteins, aggregation and motility, and host proteins, fatty-acid metabolism, intracellular transport, chaperones, hydrophobicity, QS, chemotaxis, stress responses, and EPS matrix formation. Additional external factors are also involved, such as the characteristics and physicochemical factors of the attachment surface, and the environmental conditions (Reuter et al. 2010; Sulaeman et al. 2012; Szymanski and Gaynor 2012; Giaouris et al. 2015; Kurinčič et al. 2016).

Collectively, the properties of the bacterial cell and contact surface represent the main targets for the antiadhesion activities of phytochemicals. The design of effective anti-adhesion strategies is at present limited by the lack of knowledge of $C$. jejuni cell physiology and their cell structures in relation to different attachment surfaces. Natural extracts and phytochemicals with anti-adhesion activities against $C$. jejuni will use different mechanisms of action against these pathogens. However, extracts and compounds with known anti-adhesion activities against $C$. jejuni have been poorly studied in terms of their mechanisms against bacterial adhesion.

Trans-cinnamaldehyde, carvacrol and eugenol, have been shown to reduce $C$. jejuni adhesion to an abiotic surface through an anti-adhesion mechanism that acts through reduced expression of genes involved in C. jejuni motility: $f g A$, flaA, flaB and motA (Wagle et al. 2019). In C. jejuni, flagella-mediated motility is a crucial factor for adhesion to an abiotic surface. Joshua et al. (2006) reported that aflagellate $C$. jejuni mutants that lack maf5 (located in the flagellin glycosylation locus) and fis cannot attach to glass surfaces, which shows the importance of the flagella as a mediator of this adhesion. Furthermore, Moe et al. (2010) tested the adhesion of $C$. jejuni $\triangle f l a A$, an aflagellate mutant, and $m o t A$, a flagellate but nonmotile mutant, and reported that both of these mutations impaired $C$. jejuni adherence to glass. Citrus extracts reduced $C$. jejuni motility and expression of the flaA-B genes (Castillo et al. 2014), while carvacrol modulates genes that encode for energy taxis 
(cetB), motility (motA), binding ( $c a d F)$ and attachment (jlpA) (Shrestha et al. 2019). This shows that motility itself, and not only the presence of the flagella, is important for $C$. jejuni attachment to abiotic surfaces, and their subsequent biofilm formation. Both the flagella as a structure and C. jejuni motility can be considered as targets for the anti-adhesion activities of phytochemicals.

The phytochemical EGCG has been shown to reduce $C$. jejuni adhesion (Klančnik et al. 2018a) and inhibit $C$. jejuni efflux pumps (Kurinčič et al. 2012), and thus efflux pump inhibition by EGCG can be considered as a mechanism of anti-adhesion. In $C$. jejuni, the efflux pumps have gained attention mainly as facilitators of antibiotic resistance, although their involvement spans other important areas, such as host colonisation, cell viability, bile resistance and oxidative stress (Lin et al. 2003; Akiba et al. 2006; Jeon et al. 2010; Kurinčič et al. 2012), and also adhesion to abiotic surfaces. For this review we used $C$. jejuni NCTC 11168 wild-type and its efflux pump mutants that lack the functional genes for expression of the efflux pump proteins $\mathrm{CmeB}, \mathrm{CmeR}, \mathrm{CmeF}$ (Klančnik et al. 2012), Cj1687 and CmeG, with the aim being able to determine the differences in the adhesion properties to stainless steel. The reference and mutant strains were prepared as previously described (Klančnik et al. 2012; Kovač et al. 2015), and C. jejuni adherence to stainless steel was evaluated by cell cultivability (Trošt et al. 2016; Klančnik et al. 2017a), with a 24-h incubation in Mueller-Hinton broth at $42{ }^{\circ} \mathrm{C}$ under microaerobic conditions. This was determined after washing and ultrasound treatment of the discs, and the data are presented as the numbers of $C$. jejuni cells $(\log \mathrm{CFU} / \mathrm{mL})$. The data here are shown in Fig. 5 for the involvement of the efflux pumps CmeDEF, CmeGH and Cj1687 in C. jejuni adhesion to this abiotic surface. Interestingly, the mutants that lacked functional cmeF, cmeG and cj1687 genes showed impaired adhesion, compared to the wild-type. According to these data, the efflux pumps CmeDEF, $\mathrm{CmeGH}$ and $\mathrm{Cj} 1687$ can be considered as targets for the anti-adhesion activities of these phytochemicals.

As well as the efflux pumps in the membrane, the membrane as a whole and the cell surface can be considered as targets for anti-adhesion activities. $C$. jejuni show high abundance of membrane proteins involved in adhesion and biofilm formation (Asakura et al. 2007; Sulaeman et al. 2012), which indicates the

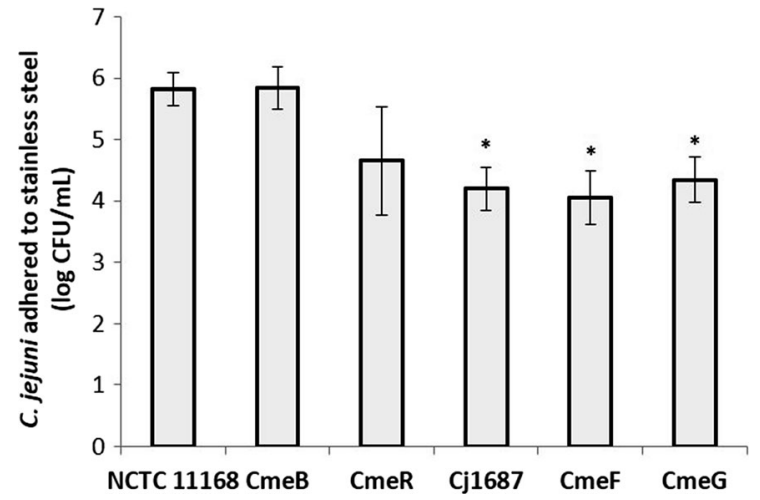

Fig. 5 Campylobacter jejuni adhered to stainless steel after $24 \mathrm{~h}$ incubation at $42{ }^{\circ} \mathrm{C}$ in a microaerobic atmosphere. The samples include wild-type $C$. jejuni NCTC 11168, and its efflux pump mutants that lack functional genes for expression of the efflux pump proteins $\mathrm{CmeB}, \mathrm{CmeR}, \mathrm{Cj} 1687, \mathrm{CmeF}$ and $\mathrm{CmeG}$ (as indicated). ${ }^{*}, p<0.01$ (Student's t-tests)

importance of membrane proteins in C. jejuni adhesion to abiotic surfaces. Furthermore, Sulaeman et al. (2012) showed a link between the expression of the $c a d F$ gene, which encodes an outer membrane protein, and $C$. jejuni adhesion. Compounds that reduced the expression of $c a d F$, such as trans-cinnamaldehyde, carvacrol and eugenol, also reduced $C$. jejuni adhesion to abiotic surfaces (Upadhyay et al. 2017; Wagle et al. 2019); thus, alterations to the $C$. jejuni membrane can be considered as one of their mechanisms of antiadhesion action.

The physiological properties of the cell surface also have an important role in $C$. jejuni adhesion to abiotic surfaces, in terms of its hydrophobicity and surface charge (Nguyen et al. 2012; Joshua et al. 2006). In $C$. jejuni, a link between cell surface hydrophobicity and adhesion to stainless steel and glass has been shown, although no relationship to cell surface charge was evident (Nguyen et al. 2011). This might be explained by the production of polysaccharides by $C$. jejuni, as their presence changes the cell surface physicochemical properties and will influence the attachment of $C$. jejuni to an abiotic surface (Gilbert et al. 2008; Nguyen et al. 2012).

Considering in particular thyme extracts, in which the major constituent is carvacrol, these are known to inhibit $C$. jejuni motility, modify the $C$. jejuni cell membrane, and reduce $C$. jejuni adhesion to polystyrene (Šikić Pogačar et al. 2016). We believe that this motility reduction and the membrane 
modifications define the main mechanisms of antiadhesion of thyme extracts, although this remains to be confirmed more directly. Indeed, the spiral-shape and motility of Campylobacter are of great importance for their attachment, and consequently for their pathogenesis (Klančnik et al. 2013, 2014; Frirdich et al. 2019). Campylobacter are well known for their morphology changes during exposure to adverse environmental conditions, and especially for transition from spiral to coccoid form (Klančnik et al. 2006), which appears to be a potentially dormant form, and also to the VBNC or degenerative form (Park 2002; Klančnik et al. 2009).

To look at this further here, we used C. jejuni K49/ 4 , with the aim to determine the morphology changes to the planktonic cells in the presence of sub-inhibitory concentrations of a 'Pinot noir' grape skin and seed extract, and of resveratrol. The electron micrograph in Fig. 6a shows the spiral morphology of the control, untreated, C. jejuni K49/4, with a flagellum at each cell pole, prepared as reported previously and observed under transmission electron microscopy (CM100; Philips Electronics, N.V. Eindhoven, The Netherlands) (Klančnik et al. 2009). When subinhibitory concentrations of the 'Pinot noir' skin and seed extract $(200 \mu \mathrm{g} / \mathrm{mL}$; Fig. $6 \mathrm{~b})$ or resveratrol (200 $\mu \mathrm{g} / \mathrm{mL}$, Fig. 6c; $100 \mu \mathrm{g} / \mathrm{mL}$, Fig. 6d) were added, different $C$. jejuni forms were seen, mainly as short bacillary forms without flagella, and as cells in clusters, with the coccoid forms rarely seen.

Many other phytochemicals have the potential for prevention of $C$. jejuni adhesion to abiotic surfaces. For example, $\alpha$-pinene (Kovač et al. 2015) is an efflux pump inhibitor and thus has the potential to influence C. jejuni adhesion via this mechanism. Two
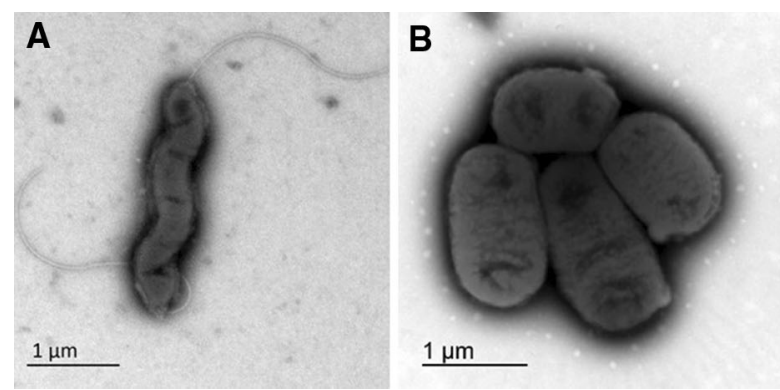

Fig. 6 Representative transmission electron micrographs showing C. jejuni K49/4 as the untreated control (a) and following treatments with 'Pinot noir' grape skin and seed terpenoids, carvone and carveol, result in the separation of Rhodococcus erythropolis cells through their decreased hydrophobicity (de Carvalho and de Fonseca 2007), and can be considered as C. jejuni antiadhesion agents. Pinostrobin acts as an inhibitor of the major facilitator superfamily type efflux pump in $S$. aureus, and is also an anti-biofilm agent (Christena et al. 2015). An essential oil from Juniperus communis has been shown to damage bacterial cell membranes (Meng et al. 2016), and it also shows significant antiadhesion activity against $C$. jejuni (Klančnik et al. 2018b). Indeed, this essential oil might inhibit $C$. jejuni adhesion via its inhibition of $\mathrm{CmeGH}$, a $C$. jejuni major facilitator superfamily efflux pump (Jeon et al. 2010). Pinocembrin modulates the metabolic activity of $C$. jejuni. At sub-inhibitory concentrations, pinocembrin did not significantly alter membrane functionality and it increased bacterial fitness. Treatment with pinocembrin evoked decreased expression of ribosomal proteins and down-regulation of several NADH dehydrogenase I chain subunits and proteins involved in iron uptake. This suggests altered protein production and redox cycle and iron metabolism. Interestingly, the chelation of $\mathrm{Fe}$ ions during the treatment with pinocembrin increased $C$. jejuni survival, although there was no increase in the formation of reactive oxygen species (Klančnik et al. 2019). Bezek et al. (2016) described an ethanol extract from E. rutaecarpa, and its fractions, that reduced QS of $C$. jejuni and also showed anti-adhesion and anti-biofilm effects against $C$. jejuni on a stainless steel surface. The anti-QS effect of this extract was seen at $0.25 \times \mathrm{MIC}$, and was shown through detection of AI-2 activity in the bioluminescence assay using $V$. harveyi (Bassler et al. 1997). Extracts of the fruit peel

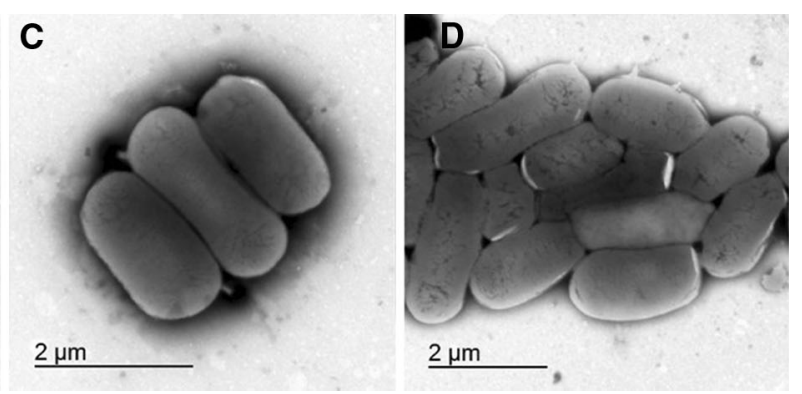

extract at $200 \mu \mathrm{g} / \mathrm{mL}$ (b), and resveratrol at $200 \mu \mathrm{g} / \mathrm{mL}$ (c) and $100 \mu \mathrm{g} / \mathrm{mL}(\mathbf{d})$. Scale bars: as indicated 
from Citrus limon, Citrus medica and Citrus aurantium were also shown to reduce QS of $C$. jejuni, along with their motility and their expression of the flaA/ $B$ genes, which are important for the initial adhesion and motility of $C$. jejuni (Castillo et al. 2014). The $C$. jejuni knock-out mutant for the luxS gene, which modulates the QS mechanism, showed reduced motility, autoagglutination, adhesion and biofilm formation on a polystyrene surface (Elvers and Park 2002; Jeon et al. 2003; Reeser et al. 2007; Šimunović et al. 2020), which indicated a role for QS in the regulation of these mechanisms (Plummer 2012). Šimunović et al. (2020) have shown a correlation of anti-QS activity of phytochemicals and their anti-adhesion activity against $C$. jejuni.

As can be concluded from the details here, only a few mechanisms are known to be involved in the successful anti-adhesion activities of the phytochemicals against $C$. jejuni. The most important appears to be motility reduction, although efflux pump inhibition, membrane integrity disruption, and QS reduction are also important and might contribute to the mechanisms of action here. Therefore, in future studies, investigations into these anti-adhesion effects of phytochemicals should also include investigation of the potential mechanisms shown here to be involved in these effects.

\section{Conclusions}

Infections by $C$. jejuni and its consequences are a major burden on healthcare and food industries. As no known measures to combat this pathogen are effective, the search for alternative strategies is encouraged. We present the reduction or prevention of Campylobacter spp. adhesion to abiotic surfaces by phytochemicals as an effective measure for Campylobacter spp. control. Many natural extracts and pure phytochemicals have been well characterized, with known antibacterial and anti-adhesion activities and known mechanisms of action. This type of compounds with known effects on C. jejuni motility, efflux pump inhibition, membrane disruption and QS inhibition can be considered and tested as anti-adhesion agents, as these factors influence $C$. jejuni adhesion greatly. An example of effective anti-adhesion agents are thyme extracts as well as the pure compounds carvacrol and thymol. These should be considered for further in vivo testing for effective C. jejuni control. Another source of effective anti-adhesion phytochemicals are waste byproducts of the agro-food industry. These by-products are a burden for the environment but could be utilized as effective $C$. jejuni adhesion control agents.

Acknowledgements Open access funding provided by University of Graz is greatly acknowledged. Authors thank the Slovenian Research Agency for funding Grant Nos. J4-9299 and P4-0116, and Prof. Dr. Magda Tušek Žnidarič from Department of Biotechnology and System Biology, National Institute of Biology, Ljubljana, Slovenia for providing representative transmission electron micrographs.

\section{Compliance with ethical standards}

Conflict of interest The authors declare that they have no conflict of interest.

Open Access This article is licensed under a Creative Commons Attribution 4.0 International License, which permits use, sharing, adaptation, distribution and reproduction in any medium or format, as long as you give appropriate credit to the original author(s) and the source, provide a link to the Creative Commons licence, and indicate if changes were made. The images or other third party material in this article are included in the article's Creative Commons licence, unless indicated otherwise in a credit line to the material. If material is not included in the article's Creative Commons licence and your intended use is not permitted by statutory regulation or exceeds the permitted use, you will need to obtain permission directly from the copyright holder. To view a copy of this licence, visit http://creativecommons.org/licenses/by/4.0/.

\section{References}

Akiba M, Lin J, Barton YW, Zhang Q (2006) Interaction of $\mathrm{CmeABC}$ and $\mathrm{CmeDEF}$ in conferring antimicrobial resistance and maintaining cell viability in Campylobacter jejuni. J Antimicrob Chemother 57(1):52-60. https://doi. org/10.1093/jac/dki419

Altemimi A, Lakhssassi N, Baharlouei A et al (2017) Phytochemicals: extraction, isolation, and identification of bioactive compounds from plant extracts. Plants (Basel) 6(4):E42. https://doi.org/10.3390/plants6040042

Asakura H, Yamasaki M, Yamamoto S, Igimi S (2007) Deletion of peb4 gene impairs cell adhesion and biofilm formation in Campylobacter jejuni. FEMS Microbiol Lett 275(2):278-285. https://doi.org/10.1111/j.1574-6968. 2007.00893.x

Atanasov AG, Waltenberger B, Pferschy-Wenzig E-M et al (2016) Discovery and resupply of pharmacologically active plant-derived natural products: a review. Biotechnol Adv 33(8):1582-1614. https://doi.org/10.1016/j. biotechadv.2015.08.001

Bacanlı M, Aydın S, Başaran AA, Başaran N (2017) Are all phytochemicals useful in the preventing of DNA damage? 
Food Chem Toxicol 109(Pt1):210-217. https://doi.org/10. 1016/j.fct.2017.09.012

Backert S, Hofreuter D (2013) Molecular methods to investigate adhesion, transmigration, invasion and intracellular survival of the foodborne pathogen Campylobacter jejuni. J Microbiol Methods 95(1):8-23. https://doi.org/10.1016/j. mimet.2013.06.031

Bassler BL, Greenberg EP, Stevens AM (1997) Cross-species induction of luminescence in the quorum-sensing bacterium Vibrio harveyi. J Bacteriol 179(12):4043-4045. https://doi.org/10.1128/jb.179/12.4043-4045.1997

Bezek K, Kurinčič M, Knauder E et al (2016) Attenuation of adhesion, biofilm formation and quorum sensing of Campylobacter jejuni by Euodia ruticarpa. Phytother Res 30(9):1527-1532. https://doi.org/10.1002/ptr.5658

Bohinc K, Dražić G, Fink R et al (2014) Available surface dictates microbial adhesion capacity. Int J Adhes Adhes 50:265-272. https://doi.org/10.1016/j.ijadhadh.2014.01. 027

Bolton DJ (2015) Campylobacter virulence and survival factors. Food Microbiol 48:99-108. https://doi.org/10.1016/j.fm. 2014.11.017

Bronnec V, Turoňnová H, Bouju A et al (2016) Adhesion, biofilm formation, and genomic features of Campylobacter jejuni $\mathrm{Bf}$, an atypical strain able to grow under aerobic conditions. Front Microbiol 7:1002. https://doi.org/10. 3389/fmicb.2016.01002

Cao H, Chai T-T, Wnag X et al (2017) Phytochemicals from fern species: potential for medicine applications. Phytochem Rev 16:379-440. https://doi.org/10.1007/s11101-016

Castillo S, Heredia N, Arechiga-Carvajal E, García S (2014) Citrus extracts as inhibitors of quorum sensing, biofilm formation and motility of Campylobacter jejuni. Food Biotechnol 28(2):106-122. https://doi.org/10.1080/ 08905436.2014.895947

Castillo S, Heredia N, García S (2015) 2(5H)-Furanone, epigallocatechin gallate, and a citric-based disinfectant disturb quorum-sensing activity and reduce motility and biofilm formation of Campylobacter jejuni. Folia Microbiol (Praha) 60(1):89-95. https://doi.org/10.1007/s12223014-0344-0

Chae MS, Schraft H (2000) Comparative evaluation of adhesion and biofilm formation of different Listeria monocytogenes strains. Int J Food Microbiol 62(1-2):103-111. https://doi. org/10.1016/s0168-1605(00)00406-2

Chen L, Teng H, Jia Z et al (2018) Intracellular signaling pathways of inflammation modulated by dietary flavonoids: the most recent evidence. Crit Rev Food Sci Nutr 58(17):2908-2924. https://doi.org/10.1080/10408398. 2017.1345853

Christena LR, Subramaniam S, Vidhyalakshmi M et al (2015) Dual role of pinostrobin - a flavonoid nutraceutical as an efflux pump inhibitor and antibiofilm agent to mitigate food borne pathogens. RSC Adv 5:61881-61887. https:// doi.org/10.1039/C5RA07165H

Curti V, Di Lorenzo A, Dacrema M et al (2017) In vitro polyphenol effects on apoptosis: an update of literature data. Semin Cancer Biol 46:119-131

de Carvalho CC, de Fonseca MM (2007) Preventing biofilm formation: promoting cell separation with terpenes. FEMS
Microbiol Ecol 61(3):406-413. https://doi.org/10.1111/j. 1574-6941.2007.00352.x

Duarte A, Alves AC, Ferreira S et al (2015) Resveratrol inclusion complexes: antibacterial and anti-biofilm activity against Campylobacter spp. And Arcobacter butzleri. Food Res Int 77(2):244-250. https://doi.org/10.1016/j.foodres. 2015.05.047

Duarte A, Luís Â, Oleastro M, Domingues FC (2016) Antioxidant properties of coriander essential oil and linalool and their potential to control Camplyobacter spp. Food Control 61:115-122. https://doi.org/10.1016/j.foodcont.2015.09. 033

Dunne WM Jr (2002) Bacterial adhesion: seen any good biofilms lately? Clin Microbiol Rev 15(2):155-166. https:// doi.org/10.1128/CMR.15.2.155-166.2002

Dwivedi R, Nothaft H, Garber J et al (2016) L-fucose influences chemotaxis and biofilm formation in Campylobacter jejuni. Mol Microbiol 101(4):575-589. https://doi.org/10. 1111/mmi.13409

EFSA (European Food Safety Authority), ECDC (European Centre for Disease Prevention and Control) (2018) The European Union summary report on trends and sources of zoonoses, zoonotic agents and food-borne outbreaks in 2017. EFSA J 16(12):5500. https://doi.org/10.2903/j.efsa. 2018.5500

EFSA (European Food Safety Authority), ECDC (European Centre for Disease Prevention and Control) (2019a) The European Union summary report on antimicrobial resistance in zoonotic and indicator bacteria from humans, animals and food in 2017. EFSA J 17(2):5598. https://doi. org/10.2903/j.efsa.2019.5598

EFSA (European Food Safety Authority), ECDC (European Centre for Disease Prevention and Control) (2019b) The European Union One Health 2018 Zoonoses Report. EFSA J 17(12):5926. https://doi.org/10.2903/j.efsa.2019.5926

Elvers KT, Park SF (2002) Quorum sensing in Campylobacter jejuni: detection of a luxS encoded signaling molecule. Microbiology 148(Pt5):1475-1481. https://doi.org/10. 1099/00221287-148-5-1475

Flemming HC, Wingender J, Szewzyk U et al (2016) Biofilms: an emergent form of bacterial life. Nat Rev Microbiol 14:563-575. https://doi.org/10.1038/nrmicro.2016.94

Frirdich E, Biboy J, Pryjma M et al (2019) The Campylobacter jejuni helical to coccoid transition involves changes to peptidoglycan and the ability to elicit an immune response. Mol Microbiol 112(1):280-301. https://doi.org/10.1111/ mmi.14269

Gamble R, Muriana PM (2007) Microplate fluorescence assay for measurement of the ability of strains of Listeria monocytogenes from meat and meat-processing plants to adhere to abiotic surfaces. Appl Environ Microbiol 73(16):5235-5244. https://doi.org/10.1128/AEM.0011407

Giaouris E, Heir E, Desvaux M, Hébraud M et al (2015) Intraand inter-species interactions within biofilms of important foodborne bacterial pathogens. Front Microbiol 6:841. https://doi.org/10.3389/fmicb.2015.00841

Gilbert M, Parker CT, Moran AP (2008) Campylobacter jejuni lipooligosaccharides: structures and biosynthesis. In: Nachamkin I, Szymanski CM, Blaser MJ (eds) 
Campylobacter, 3rd edn. ASM Press, Washington, DC, pp 483-504. https://doi.org/10.1128/978155581554.ch27

Golding CG, Lamboo LL, Beniac DR, Booth TF (2016) The scanning electron microscope in microbiology and diagnosis of infectious disease. Sci Rep 6:26516. https://doi. org/10.1038/srep26516

Gomes LC, Mergulhão FJ (2017) SEM analysis of surface impact on biofilm antibiotic treatment. Scanning 2017:2960194. https://doi.org/10.1155/2017/2960194

Harvey J, Keenan KP, Gilmour A (2007) Assessing biofilm formation by Listeria monocytogenes strains. Food Microbiol 24(4):380-392. https://doi.org/10.1016/j.fm. 2006.06.006

Hazelton PR, Gelderblom HR (2003) Electron microscopy for rapid diagnosis of infectious agents in emergent situations. Emerg Infect Dis 9(3):294-303. https://doi.org/10.3201/ eid0903.020327

Hochfellner C, Evangelopoulos D, Zloh M et al (2015) Antagonistic effect of indoloquinazoline aalkaloids on antimycobacterial activity of evocarpine. J Appl Microbiol 118(4):864-872. https://doi.org/10.1111/jam.12753

Hyytiäinen H, Hänninen ML (2012) Quality control strain Campylobacter jejuni ATCC 33560 contains a frameshift mutation in the $\mathrm{CmeR}$ regulator. Antimicrobiol Agents Chemother 56(2):1148. https://doi.org/10.1128/AAC. 06228-11

Indikova I, Humphrey TJ, Hilbert F (2015) Survival with a helping hand: Campylobacter and microbiota. Front Microbiol 6:1266. https://doi.org/10.3389/fmicb.2015. 01266

Jadhav S, Shah R, Bhave M, Palombo EA (2013) Inhibitory activity of yarrow oil on Listeria planktonic cells and biofilms. Food Control 29(1):125-130. https://doi.org/10. 1016/j.foodcont.2012.05.071

Jeon B, Itoh K, Misawa N, Ryu S (2003) Effects of quorum sensing on flaA transcription and autoagglutination in Campylobacter jejuni. Microbiol Immunol 47(11):833-839. https://doi.org/10.1111/j.1348-0421. 2003.tb03449.x

Jeon B, Muraoka WT, Zhang Q (2010) Advances in Campylobacter biology and implications for biotechnological applications. Microbiol Biotechnol 3(3):242-258. https:// doi.org/10.1111/j.1751-7915.2009.00118.x

Joshua GW, Guthrie-Irons C, Karlyshev AV, Wren BW (2006) Biofilm formation in Campylobacter jejuni. Microbiology 152(Pt2):387-396. https://doi.org/10.1099/mic.0.28358-0

Kaakoush NO, Castaño-Rodríguez N, Mitchell HM, Man SM (2015) Global epidemiology of Camplyobacter infection. Clin Microbiol Rev 28(3):687-720. https://doi.org/10. 1128/CMR.00006-15

Kalač P (2009) Chemical composition and nutritional value of European species of wild growing mushrooms: a review. Food Chem 113:9-16. https://doi.org/10.1016/j.foodchem. 2008.07.077

Klančnik A, Botteldoorn N, Herman L, Smole Možina S (2006) Survival and stress induced expression of groEL and rpoD of Camyplobacter jejuni from different growth phases. Int $\mathbf{J}$ Food Microbiol 112(3):200-207. https://doi.org/10.1016/j. ijfoodmicro.2006.03.015

Klančnik A, Guzej B, Jamnik P et al (2009) Stress response and pathogenic potential of Camplyobacter jejuni cells exposed to starvation. Res Microbiol 160(5):345-352. https://doi.org/10.1016/j.resmic.2009.05.002

Klančnik A, Smole Možina S, Zhang Q (2012) Anti-Campylobacter activities and resistance mechanisms of natural phenolic compounds in Campylobacter. PLoS ONE 7(12):e51800. https://doi.org/10.1371/journal.pone. 0051800

Klančnik A, Vučković D, Plankl M et al (2013) In vivo modulation of Campylobacter jejuni virulence in response to environmental stress. Foodborne Pathog Dis 10(6):566-572. https://doi.org/10.1089/fpd.2012.1298

Klančnik A, Vučković D, Jamnik P et al (2014) Stress response and virulence of heat-stressed Camplyobacter jejuni. Microbes Environ 29(4):338-345. https://doi.org/10.1264/ jsme2.ME14020

Klančnik A, Megušar P, Sterniša M et al (2017a) Aqueous extracts of wild mushrooms show antimicrobial and antiadhesion activities against bacteria and fungi. Phytother Res 31(12):1971-1976. https://doi.org/10.1002/ptr.5934

Klančnik A, Šikić Pogačar M, Trošt K et al (2017b) AntiCampylobacter activity of resveratrol and an extract from waste. Pinot noir grape skins and seeds, and resistance of Camp Jejuni planktonic and biofilm cells, mediated via the CmeABC efflux pump. J Appl Microbiol 122(1):65-77. https://doi.org/10.1111/jam.13315

Klančnik A, Gobin I, Vučković D et al (2018a) Reduced contamination and infection via inhibition of adhesion of foodborne bacteria to abiotic polystyrene and biotic amoeba surfaces. Int J Food Sci Technol 53:1013-1020. https://doi.org/10.1111/ijfs.13677

Klančnik A, Zorko Š, Toplak N et al (2018b) Antiadhesion activity of juniper (Juniperus communis L.) preparations against Campylobacter jejuni evaluated with PCR-based methods. Phytother Res 32(3):542-550. https://doi.org/10. 1002/ptr.6005

Klančnik A, Šimunović K, Kovač J et al (2019) The AntiCampylobacter activity and mechanisms of pinocembrin action. Microorganisms 7(12):E675. https://doi.org/10. 3390/microorganisms 7120675

Klemm P, Vejborg RM, Hancock V (2010) Prevention of bacterial adhesion. Appl Microbiol Biotechnol 88(2):451-459. https://doi.org/10.1007/s00253-010-2805-y

Kovač J, Šimunović K, Wu Z et al (2015) Antibiotic resistance modulation and model of action of (-)- $\alpha$-pinene in Campylobacter jejuni. PLoS ONE 10(4):e0122871. https:// doi.org/10.1371/journal.pone.0122871

Kurinčič M, Klančnik A, Smole Možina S (2012) Effects of efflux pump inhibitors on erythromycin, ciprofloxacin, and tetracycline resistance in Campylobacter spp. Isolates. Microbiol Drug Resist 18(5):492-501. https://doi.org/10. 1089/mdr.2012.0017

Kurinčič M, Jeršek B, Klančnik A et al (2016) Effects of natural antimicrobials on bacterial cell hydrophobicity, adhesion, and zeta potential. Arh Hig Rada Toksikol 67(1):39-45. https://doi.org/10.1515/aiht-2016-67-2720

Limoli DH, Jones CJ, Wozniak DJ (2015) Bacterial extracellular polysaccharides in biofilm formation and function. Microbiol Spectr 3(3):MB-0011. https://doi.org/10.1128/ microbiolspec.mb-0011-2014

Lin J, Sahin O, Michel LO, Zhang Q (2003) Critical role of multidrug efflux pump $\mathrm{CmeABC}$ in bile resistance and 
in vivo colonization of Campylobacter jejuni. Infect Immun 71(8):4250-4259

Lu X, Al-Qadiri HM, Lin M, Rasco BA (2011) Application of Mid-infrared and Raman spectroscopy to the study of bacteria. Food Bioprocess Technol 4:919-935. https://doi. org/10.1007/s11947-011-0516-8

Lu X, Samuelson DR, RAsco BA, Konkel ME (2012) Antimicrobial effect of diallyl sulphide on Campylobacter jejuni biofilms. J Antimicrob Chemother 67(8):1915-1926. https://doi.org/10.1093/jac/dks138

Lv F, Liang H, Yuan Q, Li C (2011) In vitro antimicrobial effects and mechanisms of action of selected plant essential oil combinations against four food-related microorganisms. Food Res Int 44(9):3057-3064. https://doi.org/10. 1016/j-foodres.2011.07.030

McDougald D, Rice SA, Weichart D, Kjelleberg S (1998) Nonculturability: adaptation or debilitation? FEMS Microbiol Ecol 25(1):1-9. https://doi.org/10.1111/j.15746941.1998.tb00455.x

Melo RT, Mendonça EP, Monteiro GP et al (2017) Intrisnic and extrinsic aspects on Campylobacter jejuni biofilms. Fron Microbiol 8:1332. https://doi.org/10.3389/fmicb.2017. 01332

Meng X, Li D, Zhou D et al (2016) Chemical composition, antibacterial activity and related mechanism of the essential oil from the leaves of Juniperus rigida Sieb. Et Zucc against Klebsiella pneumoniae. J Ethnopharmacol 194:698-705. https://doi.org/10.1016/j.jep.2016.10.050

Moe KK, Mimura J, Ohnishi T et al (2010) The mode of biofilm formation on smooth surfaces by Campylobacter jejuni. J Vet Med Sci 72(4):411-416. https://doi.org/10.1292/ jvms.09-0339

Muraoka WT, Zhang Q (2011) Phenotypic and genotypic evidence for L-fucose utilization by Campylobacter jejuni. J Bacteriol 193(5):1065-1075. https://doi.org/10.1128/JB. 01252-10

Newman DJ, Cragg GM (2016) Natural products as sources of new drugs from 1981 to 2014. J Nat Prod 79:629-661. https://doi.org/10.1021/acs.jnatprod.5b01055

Nguyen VT, Turner MS, Dykes GA (2011) Influence of cell surface hydrophobicity on attachment of Campylobacter to abiotic surfaces. Food Microbiol 28(5):942-950. https:// doi.org/10.1016/j.fm.2011.01.004

Nguyen VT, Fegan N, Turner MS, Dykes GA (2012) Role of attachment to surfaces on the prevalence and survival of Campylobacter through food systems. J Food Prot 75(1):195-206. https://doi.org/10.4315/0362-028X.JFP11-012

O'Neill J (2016) Tackling drug-resistant infections globally: final report and recommendations. http://amr-review.org/ sites/default/files/160525_Final\%20paper_with\%20cover. pdf. Accessed 20 Dec 2019

Oh E, Andrews KJ, Jeon B (2018) Enhanced biofilm formation by ferrous and ferric iron through oxidative stress in Campylobacter jejuni. Front Microbiol 9:1204. https://doi. org/10.3389/fmicb.2018.01204

Pan X, Bligh SW, Smith E (2014) Quinolone alkaloids from Fructus Euodiae show activity against methicillin-resistant Staphylococcus aureus. Phytother Res 28(2):305-307. https://doi.org/10.1002/ptr.4987
Park SF (2002) The physiology of Campylobacter species and its relevance to their role as food borne pathogens. Int $\mathrm{J}$ Food Microbiol 74(3):177-188. https://doi.org/10.1016/ S0168-1605(01)00678-X

Parkhill J, Wren B, Mungall K et al (2000) The genome sequence of the food-borne pathogen Campylobacter jejuni reveals hypervariable sequences. Nature 403:665-668. https://doi.org/10.1038/35001088

Petrovska BB (2012) Historical review of medicinal plants' usage. Pharmacogn Rev 6(11):1-5. https://doi.org/10. 4103/0973-7847.95849

Plummer PJ (2012) LuxS and quorum-sensing in Campylobacter. Front Cell Infect Microbiol 2:22. https://doi.org/ 10.3389/fcimb.2012.00022

Reeser RJ, Medler RT, Billington SJ et al (2007) Characterization of Campylobacter jejuni biofilms under defined growth conditions. Appl Environ Microbiol 73(6):1908-1913. https://doi.org/10.1128/AEM.00740-06

Reuter M, Mallett A, Pearson BM, van Vliet AHM (2010) Biofilm formation by Campylobacter jejuni is increased under aerobic conditions. Appl Environ Microbiol 76(7):2122-2128. https://doi.org/10.1128/AEM.01878-09

Rollins DM, Colwell RR (1986) Viable but nonculturable stage of Campylobacter jejuni and its role in survival in the natural aquatic environment. Appl Environ Microbiol 52(3):531-538

Rovira J, Cencic A, Santos EM, Jakobsen M (2006) Biological hazards. In: Luning PA, Devlieghere F, Verhe R (eds) Safety in the agrifood chain. Wageningen Academic Publishers, Wageningen, pp 67-143

Schluter J, Nadell CD, Bassler BL, Foster KR (2015) Adhesion as a weapon in microbial competition. ISME J 9:139-149. https://doi.org/10.1038/ismej.2014.174

Schmidt A-M, Escher U, Mousavi S et al (2019) Immunopathological properties of the Campylobacter jejuni flagellins and the adhesion CadF as assessed in a clinical murine infection model. Gut Pathog 11:24. https:// doi.org/10.1186/s13099-019-0306-9

Shirai H, Datta AK, Oshita S (2017) Penetration of aerobic bacteria into meat: a mechanistic understanding. J Food Eng 196:193-207. https://doi.org/10.1016/j.foodeng.2016. 10.012

Shrestha S, Wagle BR, Upadhyay A et al (2019) Edible coatings fortified with carvacrol reduce Campylobacter jejuni on chicken winglettes and modulate expression of select virulence genes. Front Microbiol 10:583. https://doi.org/10. 3389/fmicb.2019.00583

Šikić Pogačar M, Klančnik A, Bucar F et al (2015) Alpinia katsumadai extracts inhibit adhesion and invasion of Campylobacter jejuni in animal and human foetal small intestine cell lines. Phytother Res 29:1585-1589. https:// doi.org/10.1002/ptr.5396

Šikić Pogačar M, Klančnik A, Bucar F et al (2016) Anti-adhesion activity of thyme (Thymus vulgaris L.) extract, thyme post-distillation waste, and olive (Olea europea L.) leaf extract against Campylobacter jejuni on polystyrene and intestine epithelial cells. J Sci Food Agric 96(8):2723-2730. https://doi.org/10.1002/jsfa.7391

Šimunović K, Ramić D, Xu C, Smole Možina S (2020) Modulation of Campylobacter jejuni motility, adhesion to polystyrene surfaces, and invasion of INT407 cells by 
quorum sensing inhibition. Microorganisms 8(1):e104. https://doi.org/10.3390/microorganisms8010104

Singh D, Chaudhuri PK (2018) A review on phytochemical and pharmacological properties of Holy basil (Ocimum sanctum L.). Ind Crops Prod 18:367-382. https://doi.org/10. 1016/j.indcrop.2018.03.048

Smole Možina S, Kurinčič M, Klančnik A, Mavri A (2011) Campylobacter and its multi-resistance in the food chain. Trends Food Sci Technol 22(2-3):91-98. https://doi.org/ 10.1016/j.tifs.2010.09.003

Sterniša M, Klančnik A, Smole Možina S (2019) Spoilage pseudomonas biofilm with Escherichia coli protection in fish meat at $5{ }^{\circ} \mathrm{C}$. J Sci Food Agric 99(10):4635-4641. https://doi.org/10.1002/jsfa.9703

Sulaeman S, Hernould M, Schaumann A et al (2012) Enhanced adhesion of Campylobacter jejuni to abiotic surfaces is mediated by membrane proteins in oxygen-enriched conditions. PLoS ONE 7(9):e46402. https://doi.org/10.1371/ jounal.pone.0046402

Svensson SL, Pryjma M, Gaynor EC (2014) Flagella-mediated adhesion and extracellular DNA release contribute to biofilm formation and stress tolerance of Campylobacter jejuni. PLoS ONE 9(8):e106063. https://doi.org/10.1371/ journal.pone. 0106063

Szymanski CM, Gaynor EC (2012) How sugary bug gets through the day: recent developments in understanding fundamental processes impacting Campylobacter jejuni pathogenesis. Gut Microbes 3(2):135-144. https://doi.org/ 10.4161/gmic. 19488

Teh AH, Lee SM, Dykes GA (2014) Does Campylobacter jejuni form biofilm in food-related environments? Appl Environ Microbiol 80(17):5154-5160. https://doi.org/10.1128/ AEM.01493-14

Toplak N, Kovač M, Piskernik S et al (2012) Detection and quantification of Campylobacter jejuni and Campylobacter coli using real-time multiplex PCR. J Appl Microbiol 112(4):752-764. https://doi.org/10.1111/j.1365-2672. 2012.05235.x

Trošt K, Klančnik A, Mozetič Vodopivec B et al (2016) Polyphenol, antioxidant and antimicrobial potential of six different white and red wine grape processing leftovers. J Sci Food Agric 96(14):4809-4820. https://doi.org/10. 1002/jsfa.7981

Upadhyay A, Arsi K, Wagle BR et al (2017) Trans-cinnamaldehyde, carvacrol, and eugenol reduce Campylobacter jejuni colonization factors and expression of virulence genes in vitro. Front Microbiol 8:713. https://doi. org/10.3389/fmicb.2017.00713

Upadhyay A, Arsi K, Upadhyay I et al (2019) Natural and environmentally friendly strategies for controlling Campylobacter jejuni colonization in poultry, survival in poultry products and infection in humans. In: Venkitanarayanan K, Thakur S, Ricke S (eds) Food safety in poultry meat production. Springer, Cham, pp 67-93. https://doi.org/10.1007/978-3-030-05011-5_4

Vesterlund S, Paltta J, Karp M, Ouwehand AC (2005) Measurement of bacterial adhesion-in vitro evaluation of different methods. J Microbiol Methods 60(2):225-233. https://doi.org/10.1016/j.mimet.2004.09.013

Vinayagam R, Xiao J, Xu B (2017) An insight into anti-diabetic properties of dietary phytochemical. Phytochem Rev 16(3):535-553. https://doi.org/10.1007/s1101-017-9496-2

Wagle BR, Upadhyay A, Upadhyaya I et al (2019) Trans-cinnamaldehyde, eugenol and carvacrol reduce Campylobacter jejuni biofilms and modulate expression of selected genes and proteins. Front Microbiol 10:1837. https://doi.org/10.3389/fmicb.2019.01837

Wang XX, Zan K, Shi SP et al (2013) Quinolone alkaloids with antibacterial and cytotoxic activities from the fruits of Evodia rutaecarpa. Fitoterapia 89:1-7. https://doi.org/10. 1016/j.fitote.2013.04.007

Wang XM, Zhang J, Wu LH et al (2014) A mini-review of chemical composition and nutritional value of edible wildgrown mushroom from China. Food Chem 151:279-285. https://doi.org/10.1016/j.foodchem.2013.11.062

Winkelströter LK, Teixeira FB, Silva EP et al (2014) Unraveling microbial biofilms of importance for food microbiology. Microbiol Ecol 68(1):35-46. https://doi.org/10.1007/ s00248-013-0347-4

World Health Organization (2015) Global action plan on antimicrobial resistance. WHO, Geneva

World Health Organization (2019) WHO global report on traditional and complementary medicine 2019. Geneva, WHO: ISBN 978-92-4-151543-6

Yang P, Song H, Wang L, Jing H (2019) Characterization of key aroma-active compounds in black garlic by sensory-directed flavor analysis. J Agric Food Chem 67(28):7926-7934. https://doi.org/10.1021/acs.jafc. 9b03269

Yin R, Kuo H-C, Hudlikar R et al (2019) Gut microbiota, dietary phytochemicals, and benefits to human health. Curr Pharmacol Rep 5(5):332-344. https://doi.org/10.1007/s40495019-00196-3

Zhao C, Wu Y, Liu X et al (2017) Functional properties, structural studies and chemo-enzymatic synthesis of oligosaccharides. Trends Food Sci Tech 66:135-145. https://doi.org/10.1016/j.tifs.2017.06.008

Publisher's Note Springer Nature remains neutral with regard to jurisdictional claims in published maps and institutional affiliations. 